\title{
COMMENT
}

\section{PROTECTING THE PRESS FROM PRIVACY}

\author{
JOHN H. FUSON ${ }^{\dagger}$
}

INTRODUCTION: HAS THE PROMISE OF THE FREE PRESS FAIIED?

\author{
"And that's the way it is...." \\ -Walter Cronkite
}

Walter Cronkite's direct yet comforting closing to the evening news evoked the idyllic American image of journalism: the facts, plain and simple, honestly presented, without spin or dirt. ${ }^{2}$ The romanticized promise of First Amendment protections for a free press ${ }^{3}$-that dutiful reporters would keep citizens informed about important public matters so that they might exercise a sound and reasonable check

† B.A. 1993, Grinnell College; J.D. Candidate 2000, University of Pennsylvania. I wish to extend my sincerest thanks to three important people in my life for their love and support in the preparation of this Comment: to my wife, Amy, for her enthusiasm; to my mother, Pam, for her patience; and to my father, $\mathrm{Hal}$, for his reporter's eye and his editor's pen. I am deeply indebted to you all.

'WALTER CRONKITE, A REPORTER's LIFE 363 (1996) (describing the line that in 1963 became his signature as anchor of the CBS Evening News).

${ }^{2}$ Harry Reasoner once observed:

Walter is not a commentator. He believes as strongly as I do in being objective. I suppose if you watched him regularly over the years-from out in the country somewhere-you would have the feeling that he hates bullies where he finds them in the United States and elsewhere in the world. He hates liars. He hates pretension and he hates phonies. He is determined to report these things where he finds them. But he does as much as he can-I think successfully-to keep his personal opinions out of his broadcasts.

DOUG JAMES, WAITER CRONKIE: HIS LIFE AND TMMES 25 (1991). See generally MICHAEI EMERY \& EDWIN EMERY, THE PRESS AND AMERICA: AN INTERPRETTVE HISTORY OF THE MASS MEDIA 493-96 (8th ed. 1996) (describing Cronkite's career and the trustful approach he brought to news).

${ }^{3}$ In relevant part, the First Amendment provides that "Congress shall make no law ... abridging the freedom of speech, or of the press." U.S. CONST. amend. I. 
on the powers of government at the ballot box ${ }^{4}$-was captured in that simple phrase. ${ }^{5}$ The confidence Cronkite stirred, ${ }^{6}$ however, is all but absent from current public sentiment toward the press. ${ }^{7}$ Instead of enjoying the public's trust, the press is the target of deep cynicism. Far from heroic, it is widely perceived as dangerous, often obnoxious, and most always unprincipled. ${ }^{9}$

Popular loathing of the press may derive from disgust with the tac-

${ }^{4}$ Potter Stewart went so far as to describe the press as a fourth branch of government. See Potter Stewart, "Or of the Press," 26 HAstings L.J. 631, 634 (1975) ("The primary purpose of the constitutional guarantee of a free press was ... to create a fourth institution outside the Government as an additional check on the three official branches."). Stewart pointed to a provision of the Massachusetts Constitution drafted by John Adams to emphasize the point: "The liberty of the press is essential to the security of the state." Id,; see MASS. CONST. pt. I, art. XVI (adding that liberty of the press "ought not, therefore, to be restrained in this commonwealth. The right of free speech shall not be abridged."); see also Minneapolis Star \& Tribune Co. v. Minnesota Comm'r of Revenue, 460 U.S. 575, 585 (1983) ("[T] he press will often serve as an important restraint on government."); JAY ROSEN, GETIING THE CONNECTIONS RIGHT: PUBLIC JOURNALISM AND THE TROUBLES IN THE PRESS 82 (1996) ("By tradition, journalism aims to inform the public and act as a watchdog over government.").

${ }^{5}$ Ironically, Cronkite's closing irritated some of his superiors, including CBS News President Richard Salant, who argued that "it arrogantly implied an unerring accuracy, of which we were not capable and which we did not claim." CRONKITE, supra note 1, at 363.

During his reign as anchor of the CBS Evening News, public opinion polls consistently showed Cronkite to be "the most trusted figure in America." JAMES, supra note 2, at 26. Jack Paar captured popular sentiment when he commented jokingly on NBC's Tonight Show, "I'm not sure that I believe in God, but I do believe in Walter Cronkite." Id. at 27.

7 See State of the First Amendment, 1999: A Survey of Public Attitudes, The Freedom Forum Online (visited Oct. 8, 1999) <http://www.freedomforum.org/first/sofa/1999/ welcome.asp> ("A survey of public attitudes about First Amendment freedoms, sponsored by the First Amendment Center at Vanderbilt University, shows the public celebrates those freedoms without being entirely comfortable with them-particularly regarding the news media."). In general, polling data on public attitudes toward the press is proliferating. See, e.g., BRUCE SANFORD, DON'T SHOOT THE MESSENGER: HOW OUR GROWING HATRED OF THE MEDIA THREATENS FREE SPEECH FOR ALL OF US 14-25 (1999) (summarizing recent polling data). As Sanford notes, however, almost no comparative data exists showing trends before 1986. See id. at 14-15.

See, e.g., Joe Davidson, Morning Edition: Improving the Image of Journalists so that the Public Will Have More Trust in Them (NPR radio broadcast, Jan. 28, 1999) ("Study after study tells us the public ranks journalists not much above road kill."). In an effort to improve the press's credibility with the public, the American Society of Newspaper Editors has launched a $\$ 1$ million project aimed at improving reporting accuracy, eliminating sensationalism, reducing bias, and connecting with readers. See id. (briefly describing the project).

${ }^{9}$ See Michael Schudson, The POWER OF NEWS 3 (1995) (describing the "tabloidization of network magazine news shows"); Davidson, supra note 8 (noting that consumers often accuse the media of "going for sensationalism more than straight, factual reporting"). 
tics of the vituperative talking heads who fill news outlets-in print, on radio or television, and over the Internet-with what consumers perceive as angry words, hair-splitting arguments, and above all, a lot of noise. "Journalism," as the public popularly believes Cronkite to have practiced it, ${ }^{11}$ seemingly has been replaced with a new, sleazy, and vitriolic form of entertainment. ${ }^{12}$ Stories that now pass for "news" appear tilted toward topics that previously would have been presented, if at all, only in brown paper wrappers.

This perception grows as the major networks fill prime-time programming slots with newsmagazines like 20/20, Dateline, 48 Hours, and 60 Minutes $I{ }^{13}$ each with its own voracious appetite for late-breaking (and ratings-grabbing) headlines. Similarly, daytime soap operas have given way to talk show hosts like Leeza Gibbons, Montel Williams, Jenny Jones, and Jerry Springer, ${ }^{14}$ who pose as journalists ${ }^{15}$ while brazenly exploring the sultry backwaters of popular culture. ${ }^{16}$ Even such repositories of traditional journalistic values as the New York Times and the Washington Post have become preoccupied with the lurid details of

${ }^{10}$ See ROSEN, supra note 4, at 23-24 (describing the declining standards of journalists). But see id. at 21-22 (suggesting that talk radio, Lary King Live, and on-line chat rooms have had a positive social impact by expanding political dialogue).

${ }^{11}$ The accuracy of the public's perception is debatable. Cronkite himself recognized that almost from its advent television blurred the line between news and entertainment. He wrote:

I visualize the TV industry as a huge building dedicated to the business of entertainment. Journalism is in an attached annex next door. In that door between them is a huge vacuum that runs twenty-four hours a day threatening to suck into the larger building anyone who comes too close.

CRONKITE, supra note 1 , at 337.

${ }^{12}$ See ScHUDSON, supra note 9, at 171 (noting the "blurring of the line between news and entertainment").

${ }^{13}$ See Steve Johnson, 60 Minutes Set Standard-Can II Do It Too?, GrI. TRIB., Jan. 13, $1999, \$ 5$, at 1 (reporting the rapid growth of primetime newsmagazines).

${ }^{14}$ Cf. SCHuDson, supra note 9, at 179 (citing Donahue as "the model of entertainment that feeds on the news").

${ }^{15}$ The producers of $L E E Z A$, for example, tout the show for its focus on breaking news and current events and "for allowing audience members to speak out about issues making news." LEEZA (visited Sept. 28, 1999) <http://www.paramount.com/tvleeza/ leeza_body.html.

${ }^{16}$ A random sampling of recent topics includes "Extreme Sex Fetishes" and "Back Stabbing Best Friends" on the Jerry Springer Show, see Jerry Springer Show and Fan Club Website (visited Sept. 28, 1999) <http://www.jerryspringer.com/showschedule.asp>, "Families Divided by Race" and "My Teen Is Ruining My Relationship" on The Montel Williams Show, see The Montel Williams Show (visited Sept. 28, 1999) <http:// www.montelshow.com>, and "Don't Be So Cruel, Stop Harassing Me at School" and "Jenny, I Want to Lie Detector My Ex" on the Jenny Jones Show, see Jenny Jones Talk Show (visited Sept. 28, 1999) <http://jennyjones.warnerbros.com>. 
the President's private life. ${ }^{17}$ Thus, media are not limited to fictional dramas to satisfy the public's taste for sleaze. The news offers similar plot lines with an added twist of enticement: the stories and people are real.

Taken together, popular perceptions about the direction of journalism leave many with the state of mind of legendary anchorman Howard Beale in the movie Network who cried out, "I'm as mad as hell and I'm not going to take it anymore. ${ }^{18}$ Americans generally, and perhaps pathologically, turn to the law whenever institutions irritate them, whether by brewing the coffee too hot, ${ }^{19}$ not finishing the paint with a professional edge, ${ }^{20}$ or leaving passengers locked in airplane cabins when weather socks in an airport with insufficient gates. ${ }^{21}$ Unlike McDonald's, BMW, and Northwest Airlines, however, the press's exposure to legal rules is sharply restricted by the First Amendment. Indeed, in the 1960s and 70s, the courts responded to legal assaults against the press by reinforcing the barriers to the classic remedies for obstreperous journalism: libel judgments, ${ }^{22}$ prior restraints, ${ }^{23}$ and cita-

${ }^{17}$ See, e.g., Andrew Jay McClurg, Bringing Privacy Law Out of the Closet: A Tort Theory of Liability for Intrusions in Public Places, 73 N.C. L. REV. 989, 1012-13 (1995) (noting that during the first two years of Bill Clinton's presidency, newspapers and magazines published more than twice as many articles about his sex life than the fiercely controversial Brady Bill).

${ }_{18}$ NETWORK (Metro-Goldwyn-Mayer 1976).

${ }^{19}$ See, e.g., McMahon v. Bunn-O-Matic Corp., 150 F.3d 651, 659 (7th Gir. 1998) (affirming summary judgment for the defendant coffee-maker manufacturer in a case brought by a plaintiff who suffered second- and third-degree burns when she spilled coffee on her lap); Mike Rosen, Coffee and \$2.9 Million to Go, DENVER POST, Aug. 26, 1994, at B11 (reporting on a more notorious case in which a plaintiff successfully sued McDonald's after a similar mishap involving a hot cup of coffee).

${ }^{20} \mathrm{See}$ BMW of North America, Inc. v. Gore, 517 U.S. 559, 585 (1996) (reversing a jury's $\$ 4$ million judgment in a fraud case brought against BMW by the purchaser of a new car after he discovered the car had been partially repainted before sale, finding the award "grossly excessive"); Joan Biskupic, The Case of the \$4 Million BMW: Award to Owner of Repainted Car Is at Heart of Punitive Damages Debate, WASH. POST, May 29, 1995, at $\mathrm{A} 4$ (reporting on reactions to the lawsuit).

${ }^{21}$ See Steve Twomey, On a Runway to Nowhere on a Snowy Day in Detroit: Only Frustration Was Plentiful for Those Stuck on Planes, WASH. POST, Jan. 29, 1999, at A1 (describing the events that led to a lawsuit against Northwest Airlines by passengers who were trapped in airplanes for up to nine hours when snowstorms snarled traffic at the Detroit airport).

${ }_{22}^{2}$ In New York Times Co. v. Sullivan, 376 U.S. 254 (1964), for example, the Supreme Court reversed a libel judgment against the New Yonk Times, holding that constitutional guarantees require ... a federal rule that prohibits a public official from recovering damages for a defamatory falsehood relating to his official conduct unless he proves that the statement was made with "actual malice" - that is, with knowledge that it was false or with reckless disregard of whether it was false or not.... 
tions for contempt. ${ }^{24}$

Seeking ways around First Amendment restrictions, irritated plaintiffs and irritable juries have sought out other causes of action, both old and new, from breach of contract to intentional infliction of emotional distress. ${ }^{25}$ Fed by a century of academic hypothesizing, ${ }^{26}$ as well

Id. at 279-80.

${ }_{23}$ In Nebraska Press Ass'n v. Stuart, 427 U.S. 539 (1976), for example, the Supreme Court rejected a prior restraint imposed to protect a criminal defendant's right to a fair trial, holding that "prior restraints on speech and publication are the most serious and least tolerable infringement on First Amendment rights." Id. at 559. Similarly, in New York Times Co. v. United States, 403 U.S. 713 (1971), the Court rejected a prior restraint against publication of the famed "Pentagon Papers" despite the government's stated national security concerns. In concurrence, Justice Brennan observed that "the First Amendment tolerates absolutely no prior judicial restraints of the press predicated upon surmise or conjecture that untoward consequences may result." Id. at 72526 (Brennan, J., concurring).

${ }_{24}$ See Branzburg v. Hayes, 408 U.S. 665, 708-09 (1972) (upholding contempt citations against journalists who refused to appear before a grand jury and disclose information obtained during the investigation of a story). Justice Powell's opinion in Branzburg, see id. at 709-10 (Powell, J., concurring), laid the groundwork for a long series of lower court decisions upholding a privilege for journalists who refuse to divilge sources or other confidential information. See, e.g., United States v. Burke, 700 F.2d 70, 77-78 (2d Cir. 1983) (quashing subpoena for magazine's notes and other materials, finding that the criminal defendant failed to show compelling need), cert. denied, 464 U.S. 816 (1983); Zerilli v. Smith, 656 F.2d 705, 713-15 (D.C. Cir. 1981) (denying motion to compel reporters to disclose sources because plaintiffs failed to show that they had exhausted alternative sources of information); Miller v. Transamerrican Press, Inc., 621 F.2d 721, 725 (5th Cir. 1980), modified, 628 F.2d 932 (5th Cir. 1980) (holding that a reporter subpoenaed by a public figure libel defendant has a First Amendment privilege against disclosure of confidential source), cert. denied, 450 U.S. 1041 (1981). See generally James C. Goodale, A Sigh of Relief, N.Y.L.J., Oct. 1, 1999, at 3 (noting that in over 400 reported cases, media have pointed to Powell's opinion to defend against disclosure of sources, "usually with favorable results"). More recently, however, some courts have begun to question such a reading of Branzburg. See, e.g., In re Grand Jury Proceedings, 810 F.2d 580, 583-84 (6th Cir. 1987) (holding that a television reporter has no First Amendment privilege to refuse to give testimony about interviews of gang members implicated in a slaying); State ex rel. NBC v. Court of Common Pleas, 556 N.E.2d 1120, 1126-27 (Ohio 1990) (questioning the rationale of Burke, Zerilli, and Miller and upholding an order to a television station to preserve its tapes pending issuance of a subpoena in a criminal proceeding). See generally James C. Goodale et al., Reporters Privilege, in COMMUNICATIONS LAw 1998, at 71-76 (Practising Law Institute 1998) (discussing the confidentiality issues raised by this line of cases).

${ }^{25}$ See, e.g., Cohen v. Cowles Media Co., 501 U.S. 663, $671-72$ (1991) (permitting invocation of a breach of contract claim to hammer news media for identifying plaintiff's identity as a source); Hustler Magazine v. Falwell, 485 U.S. 46, 50 (1988) (rejecting an attempt to convert a libel claim into an action for emotional distress); Jefferson County v. Moody's, 175 F.3d 848, 856-58 (10th Cir. 1999) (rejecting plaintiff's attempt to paint unflattering opinions as tortious interference with contract); Berger v. Hanlon, 129 F.3d 505, 510 (9th Cir. 1997) (permitting claims of civil rights violations against a television crew that accompanied a raid by federal agents), vacated, $119 \mathrm{~S}$. Ct. 1706 (1999). 
as a trickle of actual lawsuits dating back to the early $1900 \mathrm{~s},{ }^{27}$ no area is more ripe for the entry of the media-scourges' Trojan horses than the various renditions of the purported privacy torts.

The desire to protect the personal privacy of citizens from a prying government is understandable, indeed constitutionally required, as the Fourth Amendment makes clear. ${ }^{28}$ Protection of personal privacy from private individuals or institutions bent on using personal information to perpetrate fraud or blackmail also is laudable. Using

${ }^{26}$ Privacy law all but begins with Samuel Warren's and Louis Brandeis's legendary 1890 law review article attacking the press for unflattering portrayals of matters involving Warren's family that he believed should not have been published. See Samuel D. Warren \& Louis D. Brandeis, The Right to Privacy, 4 HARV. L. REV. 193 (1890). Subsequent efforts to define the "right to be let alone" as prescribed by Warren and Brandeis have been frequent and voluminous. For a short sampling, see, for example, Harry Kalven Jr., Privacy in Tort Law-Were Warren and Brandeis Wrong?, 31 LAW \& CONTEMIP. PROBS. 326 (1966) (arguing that various factors have dulled the "normal critical sense of judges," causing them not to appreciate "the pettiness of the tort"); Melville B. Nimmer, The Right to Speak from Times To Time: First Amendment Theory Applied to Libel and Misapplied to Privacy, 56 CAI. L. REV. 935 (1968) (arguing that speech is less worthy of protection in invasion of privacy cases than in libel cases); Robert $C$. Post, The Social Foundations of Privacy: Community and Self in the Common Law Tort, 77 CAL. L. REV. 957 (1989) (arguing that privacy safeguards social norms that constitute individual and community identity, and that the expansion of mass media threatens those identities); William L. Prosser, Privacy, 48 CAL. L. REV. 383 (1960) (setting forth a structure of privacy analysis that has been widely adopted by the courts); and John W. Wade, Defamation and the Right of Privacy, 15 VAND. L. REV. 1093 (1962) (comparing the tort of invasion of privacy to the tort of defamation and arguing that the latter may eventually supplant the former).

${ }^{27}$ See, e.g., Time, Inc. v. Hill, 385 U.S. 374, $397-98$ (1967) (denying recovery to a private individual against the publishers of a fictionalized account of the kidnapping of his family); Haynes v. Alfred A. Knopf, Inc., 8 F.3d 1222, 1232-33 (7th Cir. 1993) (finding that author Nicholas Lemann's account of the personal details of a couple's relationship was newsworthy in the context of a book about black migration to the North); Virgil v. Time, Inc., 527 F.2d 1122, 1127-31 (9th Cir. 1975) (finding that disclosure of the odd personal quirks of a well-known California surfer presents a possible basis of action for disclosure of private facts); Sidis v. F-R Publ'g Corp., 113 F.2d 806, 809-10 (2d Cir. 1940) (finding that a magazine account of the reclusive adult life of a onetime publicly prominent child prodigy is not actionable as privacy invasion); Briscoe v. Reader's Digest Ass'n, 483 P.2d 34, 43-44 (Cal. 1971) (holding that a truck driver whose eleven-year-old criminal record was disclosed in an article on hijackings must establish that the magazine acted with reckless disregard for the fact that reasonable persons would find such an invasion "highly offensive"); Barber v. Time, Inc., 159 S.W.2d 291, 295 (Mo. 1942) (upholding a damage award for a woman pictured in her hospital room despite her objections to reporters); Melvin v. Reid, 297 P. 91,93 (Cal. Dist. Ct. App. 1931) (holding that the passage of time may limit the right to disseminate otherwise public facts).

${ }^{28}$ The Fourth Amendment protects against government intrusions of privacy, providing that " $[t]$ he right of the people to be secure in their persons, houses, papers, and effects, against unreasonable searches and seizures, shall not be violated." U.S. CONST. amend. IV. 
privacy protection as a shield to keep secrets from the public or as a club to suppress the truth about newsworthy events, however, is another matter. Appropriate in some contexts, perhaps, ${ }^{29}$ but unless closely tethered, it is a dangerous weapon against the democratic values and individual rights embodied in the First Amendment. Keeping the tether tight is not typically a great concern, however, for those who would use the privacy torts to punish or get even with rascally members of the press. Given journalists' low standing in public opinion polls, ${ }^{30}$ attacks on the press are far more likely to draw cheers than jeers.

We live in a society that already enjoys broad privacy protections. Laws exist that protect against harassment and trespass as well as defamatory speech. ${ }^{31}$ Furthermore, we often live in secluded suburbs with large yards separating us from our neighbors. ${ }^{32}$ We work in vast cities through which we move with relative anonymity. ${ }^{33}$ We commute

${ }^{29}$ See, e.g., Benitez v. KFC Nat'l Management Co., 714 N.E. 2d 1002, 1007 (Ill. App. Ct. 1999) (categorizing a former female employees' suit against the restaurant based on alleged spying through a hole in the ceiling of the women's bathroom as an actionable tort of intrusion upon the seclusion of another).

${ }^{30}$ See supra notes 7-9 and accompanying text (discussing data on public opinion toward the press).

${ }^{31}$ See, e.g., CAL. Giv. CODE $\$ \S 4446$ (West 1982) (establishing a civil action for defamation); CAL. Crv. PROC. CODE $\$ 527.6$ (West Supp. 1999) (prohibiting harassment); CAL. PENAL CODE $\$ \S 240,242$ (West 1999) (prohibiting photographers from engaging in unwanted physical contact); CAL. PENAL CODE $\$ 602.5$ (West 1999) (prohibiting trespass on private property); CAL. PENAL CODE $\$ 649.6$ (West 1999) (establishing criminal guidelines against stalking); N.Y. PENAL LAW $\$ \S 120.00,120.05,120.10$ (McKinney 1998 \& Supp. 1999) (prohibiting photographers from engaging in unwanted physical contact); N.Y. PENAL LAW $\S \S 120.20,120.25$ (McKinney 1998) (criminalizing reckless endangerment); N.Y. PENAL LAW $\S \S 140.05,140.10,140.15$ (McKinney 1999) (prohibiting trespass on private property); N.Y. PENAI LAW $\S \S 240.24$, 240.26 (McKinney Supp. 1999) (establishing criminal guidelines against stalking); N.Y. PENAL LAW §§ 240.25, 240.26 (McKinney Supp. 1999) (prohibiting harassment). Common law decisions and practices reinforce these privacy protections. See Galella v. Onassis, 487 F.2d 986, 995 (2d Cir. 1973) (upholding an injunction against photographers based on findings of harassment, assault and battery, and invasion of privacy); Randell Boese, Redefining Privacy? Anti-Paparazzi Legislation and Freedom of the Press, 17 COMM. LAw. 1, 1-3 (1999) (describing successful criminal cases against journalists for harassment and unlawful wiretapping brought by Jackie Onassis, Arnold Schwarzeneggar, Nicole Kidman, and Tom Cruise); see generally HAROLD W. FUSON JR., TELLING IT AIL: A LEGAL GUIDE TO THE EXERCISE OF FREE SPEECH 51-60 (1995) (describing for journalists the various rules governing "news-gathering fouls" that they must observe).

${ }^{32}$ See Jonathan Franzen, Imperial Bedroom, THE NEW YORKER, Oct. 12, 1998, at 48, 51 ("It's no longer the rule that you know your neighbors.").

${ }^{33}$ See id. (noting that by contrast, "[i]n 1890, an American typically lived in a small town under conditions of near-panoptical surveillance"). 
in the seclusion of our personal automobiles. ${ }^{34}$ We communicate via e-mail using imaginary screen names, ${ }^{35}$ and increasingly, we shop over the Internet from the solitude of our homes. ${ }^{36}$ Indeed, one writer has observed that "[f]ar from disappearing, [the right to be let alone is] exploding. ... [W] e're flat-out drowning in privacy.",37

This Comment explores recent developments in California that illustrate the problems pervading efforts to use tort law to expand privacy and limit access to personal information. ${ }^{38}$ First, the California Supreme Court handed down decisions in Shulman v. Group W Productions, Inc. ${ }^{39}$ and Sanders $v$. American Broadcasting $\mathrm{Co}^{40}$ broadening the scope of civil claims for intrusion. The media, the court held, may not "play tyrant to the people by unlawfully spying on them in the name of newsgathering." "paparazzi law," Senate Bill 262, ${ }^{42}$ which amended the state's privacy protection statute. ${ }^{43}$ In the words of its author, the bill is aimed at de-

${ }^{34}$ One writer observed that:

[T] he latest S.U.V.s are the size of living rooms and come with onboard telephones, CD players, and TV screens; behind the tinted windows of one of these high-riding, I-see-you-but-you-can't-see-me mobile PrivacyGuard $\circledast$ units, a person can be wearing pajamas or a licorice bikini, for all anybody knows or cares.

See id.

${ }^{35}$ See Andrew Leonard, We've Got Mail-Always, NEwSWEER, Sept. 20, 1999, at 58, 59 (noting that the "mind-boggling" growth of e-mail worldwide now allows 225 million people to send and receive electronic messages).

See Steven Levy, xmas.com, NEWSWEEK, Dec. 7, 1998, at 50, 51 (reporting on the proliferation of Internet-based holiday shopping).

${ }^{37}$ Franzen, supra note 32, at 51.

${ }^{38}$ The late Chicago newspaper columnist Mike Royko, a noted student of the deficiencies of California, once wished that a fence could be built around the state. In the end, he concluded it would be a fruitless gesture; the residents would just float over. See Interview with Doug Moe, author of The World of Mike Royko, (Nov. 29, 1999); see also Steve Harvey, Only in L.A., L.A. TMES, May 1, 1997, at B4 (reflecting on Royko's thoughts on California); Jack Smith, Freeway Follies Knocking Em Dead Back East, L.A. TIMES, Sept. 2, 1987, §5, at 1 (same). There are other reasons, grounded more firmly in legal scholarship, for focusing on California's importance to the evolution of the law, especially as it touches on celebrity, but Royko's is as telling as any.

955 P.2d 469 (Cal. 1998).

978 P.2d 67 (Cal. 1999).

${ }^{41}$ Shulman, 955 P.2d at 497.

42 See Governor's Office of the State of California, Wilson Signs Legislation to Protect Privacy Rights (Press Release, Sept. 30, 1998) (discussing legislation that protects "the personal safety and privacy rights of Californians from irresponsible members of the press") [hereinafter Governor's Office].

${ }^{43}$ See CAL. CTV. CODE $§ 1708.8$ (West Supp. 1999) (setting parameters of liability for invasion of privacy). 
terring “'paparazzi-like' behavior by photographers, reporters, and the press."

This Comment does not seek to diminish the obvious importance of privacy in all its various permutations. We must not, however, use it as an all-purpose weapon to silence news reporting we find distasteful. ${ }^{45}$ Regrettably; the court's decisions in Shulman and Sanders and the legislature's actions against paparazzi bring us a little bit closer to that result.

Theodore Roosevelt once noted that " $[t]$ he men with the muckrake are often indispensable to the well-being of society, but only if they know when to stop raking the muck. ${ }^{346}$ As this Comment seeks to explain, it is impossible to draw a universal line in the sand-or the muck - that protects privacy entirely without unduly compromising other social values.

\section{THE SHULMANDECISION}

Shulman v. Group W Productions, Inc. centers on a broadcast segment from On Scene: Emergency Response, a television program produced by the defendant that follows the real-life experiences of emergency rescue teams. ${ }^{47}$ In June 1990, Mercy Air, an operator of rescue helicopters, dispatched a helicopter to the scene of a serious automo-

44 Amy D. Hogue \& Anthony J. Stanley, California's Anti-Paparazzi Statute: How Does It Change the Law?, LIBEL DEFENSE RESOURCE CENTER BULL. (Libel Defense Resource Ctr., New York, N.Y.), Dec. 23, 1998, at 27 (quoting State Senator John Burton).

${ }^{45}$ See Diane L. Zimmerman, Requiem for a Heavyweight: A Farewell to Warren and Brandeis's Privacy Tort, 68 CORNELI. L. REv. 291, 293 (1983) (asserting that even the most aggressive advocate of privacy rights recognizes that absolute protection would "intolerably hamper human discourse").

${ }^{16}$ President Theodore Roosevelt, Address in Washington, D.C. (Apr. 14, 1906), in ROBERT ANDREWS, THE COLUMBIA DICTIONARY OF QUOTATIONS 730 (1993). Roosevelt coined the term "muckrakers" in reference to early twentieth centuryjournalists whose stinging prose exposed many of the worst abuses of industrial society. See, e.g., PAUL S. BOYER ET AL., THE ENDURING VISION: A HISTORY OF THE AMERICAN PEOPLE 736-37 (2d ed. 1993) (citing a series of articles published in 1903 by Maria Van Vorst that described the working conditions in a Massachusetts shoe factory "where women's fingernails literally rotted off because they continually had to immerse their hands in caustic dyes"). Among the more famous muckrakers were Upton Sinclair, whose stomach-turning descriptions in The Jungle brought about reforms in the meatpacking industry, and Jacob Riis, who wrote jarringly about the appalling conditions in immigrant slums. See id. at $727,749$.

${ }^{17}$ See 955 P.2d at 475 (discussing On Scene). On Scene is now defunct, see Maura Dolan, The Right to Know vs. the Right to Privacy, L.A. TmES, Aug. 1, 1997, at A1, although similar programs such as Cops and Emergency 911 continue to air. See id. 
bile accident involving the plaintiffs, Ruth Shulman and her son. ${ }^{48}$ The helicopter carried a pilot, a medic, a flight nurse, Laura Carnahan, who wore a small microphone, and a video camera operator, Joel Cooke, who worked for the defendant. ${ }^{49}$

Carnahan treated Shulman at the accident scene before transporting her to a hospital with her son on the Mercy Air helicopter. ${ }^{50}$ She suffered severe injuries that left her paralyzed from the waist down. ${ }^{51}$ Cooke shot extensive footage at the scene and on the flight back to the hospital. ${ }^{52}$ The microphone recorded Carnahan's conversations with the pilot, with other emergency personnel at the scene, and with Shulman. ${ }^{53}$ The producers then compiled the audio and video footage to create a nine-minute segment for television broadcast. ${ }^{54}$ The following extended description of the program is included to illustrate both the newsworthiness of the material and the privacy concerns that it raised.

The segment is an intense, tightly edited piece. It begins with the dispatch and flight of the helicopter to the scene. ${ }^{55}$ The viewer first learns about the accident and potential victims from the narrator who reports that "a family car has flown off the freeway and landed upsidedown, trapping a mother and her son. ${ }^{56}$

At the scene, Carnahan hears a report from an emergency medical technician, who describes the situation and instructs Carnahan to extricate Shulman and her son from the car. ${ }^{57}$ Carnahan then dis-

43 See id. (explaining that Ruth and her son were trapped in the car). Shulman's husband and nineteen-year-old daughter were also involved in the accident which occurred when the daughter lost control of the vehicle and it plunged down an embankment. See Kenneth Ofgang, C.A. Reinstates Privacy Claims over Television Taping of Rescue, METRO. NEwS-ENTER., Dec. 16, 1996, at 1 (describing the Shulmans' accident). The husband and daughter were not seriously hurt, however, and were not included in the broadcast. See Dolan, supra note 47.

49 See Shulman, 955 P.2d at 475 .

${ }^{50}$ See id. at $475-76$.

51 See id. at 476.

52 See id. at $475-76$.

${ }^{53}$ See id. at 476 .

${ }^{54}$ See id. at 475. 1990).

${ }^{55}$ See On Scene: Emergency Response (Group W Productions Broadcast, Sept. 29,

${ }^{56} I d$. As they approach the accident scene, the pilot expresses concern that a crowd of onlookers and nearby power lines will make landing the helicopter more difficult. See id.

${ }^{57}$ See id. The EMT tells Carnahan:

Here's what I've got. I've got a critical. She's got an extrication time of over twenty minutes. She's trapped underneath the vehicle. The vehicle is on top 
cusses the situation with several firefighters. ${ }^{58}$ Gasoline has leaked from the car and she wants to assure the safety of others at the site. ${ }^{59}$

Three minutes into the program, the viewer hears Carnahan speaking to Shulman for the first time.

Carnahan: "Can you speak to me, ma'am?"

Shulman: "I can talk."

Carnahan: "Can you talk? Good girl. Can you-Tell me how old you are, ma'am."

Carnahan investigates the situation under the car.

Shulman: "I'm old."

Carnahan: "How old?"

Shulman: "Forty-seven." old." ${ }^{\text {61 }}$

Carnahan: "Forty-seven? Well, it's all relative-you're not that

Carnahan then asks Shulman what year it is, and it becomes apparent that Shulman is disoriented and unable to respond. ${ }^{62}$

The firefighters now use a tool called the "Jaws of Life" to extricate Shulman and her son from the car. The narrator explains that Carnahan will climb into and under the car, which is leaking gasoline, in order to reach her patient. ${ }^{63}$ A brief shot of Shulman's bloody knee protruding from the car is seen while the viewer hears Carnahan and the medic struggle to keep contact with the patient. ${ }^{64}$ The narrator explains the danger: there is no way to access the car battery and thus the electrical system is still on; there is a high possibility of a spark that could ignite the leaking gasoline. ${ }^{65}$ The viewer can see the gasoline

of her.... I want you to take the-um-lady who's trapped with an ETA of probably twenty minutes for extrication, probably to Loma Linda [hospital], and also if you can go ahead and take the male with her. But he's alert and Id. alright. He's fine. There's no problem.

${ }^{53}$ See id. To emphasize the gravity of the situation and the magnitude of the response by public services, the narrator explains that "[a]lready on scene are county firefighters, rescue crews from the California Department of Forestry, the California Highway Patrol, and numerous EMT ambulance crews." Id.

${ }_{59}$ See id.

${ }^{\infty}$ Id.

61 Id.

${ }^{62}$ See $i d$. Carnahan asks in short succession without receiving any audible responses from Shulman: "What's the year? . . Can you guess? . . . Tell me your name." Id.
${ }^{63}$ See id.
at See id.
${ }^{65}$ See id. 
leaking from the car onto Carnahan. ${ }^{66}$

Carnahan continues to talk to Shulman, whom she now identifies as "Ruth." Looking under the car, the camera catches a brief shot of Shulman's bloody arm. ${ }^{68}$ The narrator explains that Carnahan recognizes that Shulman has suffered a severe back injury and is attempting to identify its location. ${ }^{69}$ This will complicate an already difficult extrication from the crushed automobile, as Carnahan does not want to make the injury worse. The narrator also explains that Carnahan suspects a possible head injury because her patient is "disoriented and confused. ${ }^{70}$

Shulman says, "Tell me I'm dreaming" and asks, "Where's my family?" as she is pulled from the car. ${ }^{71}$ A shot of her torso is visible during her extrication. ${ }^{72}$ "This is terrible-am I dreaming?" she asks again in disbelief. Her chin and upper torso are visible behind a medic. "Please help me," she insists. "What happened? ... Where's

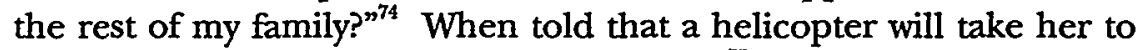
the hospital, she exclaims, "Are you teasing?"75

The narrator recounts the gravity of the situation, the potential for life-threatening tragedy, and the heroic efforts of the rescue team and firefighters. ${ }^{76}$ As Shulman is loaded onto the helicopter, firefighters and other personnel at the scene completely block her face from view. She again asks if she is dreaming and then states, "I just want to die." $"$ "77

Carnahan reassures her: "No, you do not want to die, hon. You're going to do real well." 78

As the helicopter doors close, Shulman says again, "I want to die. I don't want to go through this." ${ }^{79}$

Carnahan continues to assure her: "You don't want to die, hon.

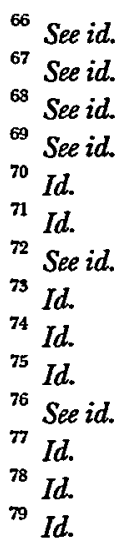


You're doing real well. You want to hang in there now. You're not that bad off." ${ }^{80}$

A little after seven minutes into the program, the scene shifts to onboard the helicopter. ${ }^{81}$ Shulman is intermittently visible for short moments, though an oxygen mask now hides her face. A member of the rescue team communicates with the hospital, explaining that Shulman is unable to move her feet. ${ }^{82}$ The narrator, meanwhile, explains the nature of the service provided by Mercy Air. ${ }^{83}$ Carnahan reports to the hospital that Shulman has a regular pulse and provides an update on her blood pressure. She leans over and reassures her patient. $^{84}$

Eight and one-quarter minutes into the program, the helicopter lands at the hospital. Shulman is unloaded, but it is now dusk, and it is impossible to identify her face in the shadows. She tells Carnahan, "My upper back hurts" and "I don't feel very good."

Carnahan is sympathetic, acknowledging, "I'm sure you don't."

Shulman is last heard as rescuers wheel her into the hospital asking, "Who else is in the accident?"

After nine minutes, the piece ends with the following text on screen: "Laura's patient spent months in the hospital. She suffered severe back injuries. The others were all released much sooner. ${ }^{n 8}$ At no time does the program ever fully identify Shulman. ${ }^{89}$ Carnahan refers to her on a few occasions only by her first name. The shots of Shulman are fleeting and they never provide an identifiable view of

${ }^{80} I d$.

${ }^{81}$ See id.

82 See id.

${ }^{83}$ See id. ("While Mercy Air is privately owned, and it's not part of any hospital chain, these men and women still respond twenty-four hours a day, every day, to calls for help, whether their patients can pay them or not.").

${ }^{84}$ See id. ("You're doing very well. We're going to land here at the hospital where you'll be transferred to the emergency room. They're going to take care of you.").

${ }^{85} \mathrm{Id}$.

${ }^{86} I d$.

${ }^{87} I d$.

8s Id. The narrator closes by saying, "Thanks to the efforts of the crew of Mercy Air, the firefighters, medics, and police who responded, all six patients lives were saved." Id. There were, in fact, only four patients. As the court observed, the program erroneously reported that four, not two, persons were evacuated from the scene by ambulance. See Shulman v. Group W Prods., Inc., 955 P.2d 469, 475 (Cal. 1998).

${ }^{89}$ See Shulman, 955 P.2d at 475-76 ("Ruth is shown several times, either by brief shots of a limb or her torso, or with her features blocked by others or obscured by an oxygen mask. She is also heard speaking several times. Carnahan calls her 'Ruth' and her last name is not mentioned on the broadcast."). 
her face. Six and three-quarters minutes of the program take place at the accident scene. It includes less than one minute of footage from the helicopter flight back to the hospital, in which Shulman's body is discernible for only a few seconds and her voice is never heard.

The program was broadcast three months after the accident in an episode of On Scene: Emergency Response without Shulman's permission. $^{90}$ She and her son brought two causes of action against the producers of the program for invasion of privacy. Their first claim was for publication of private facts stemming from the broadcast of the report on the accident. The second claim was for intrusion into the realm of personal privacy, based on the videotaping of the accident scene and the helicopter flight, and on the recording of Shulman's conversations with Carnahan. ${ }^{91}$ The trial court granted summary judgment to the producers, determining that the events depicted in the broadcast were newsworthy and therefore the First Amendment protected their activities. $^{92}$ The California Court of Appeal, however, reversed the judgment, finding triable issues of fact as to Shulman's claim for publication of private facts and error as to both plaintiffs' intrusion claims. ${ }^{93}$ The producers appealed that decision to the California Supreme Court.

\section{A. News and Entertainment Collide}

On Scene: Emergency Response is an example of reality-based television, ${ }^{94}$ a common new format for programs filling the ever-expanding airways. ${ }^{95}$ Viewers who watch such shows generally regard them as en-

${ }^{90}$ See Ofgang, supra note 48 , at 1 . Shulman apparently became aware of the broadcast from her hospital room after her son called to tell her: "Channel 4 is showing our accident now." Shulman, 955 P.2d at 476.

${ }^{91}$ See Shulman, 955 P.2d at 477.

92 See id. at 467.

93 See id.; Shulman v. Group W Prods., Inc., 59 Cal. Rptr. 2d 434, 463 (Ct. App. 1997).

${ }^{94}$ One commentator defines "reality-based television" as "a genre of television programming often featuring live video coverage of dramatic events. Popular segments include footage of officers stopping, questioning, searching, or arresting motorists, and emergency response teams, such as firefighters or paramedics, responding to calls for assistance." McClurg, supra note 17, at 991 n.1; see also Gary Williams, The Right of Privacy Versus the Right to Know: The War Continues-Forward, 19 LOY. L.A. ENT. L.J. 215, 217 (1999) (including On Scene in the genre of "reality programming").

${ }^{95}$ See Williams, supra note 94, at 217 (describing "the explosion of 'reality programming' with its insatiable appetite for visual and aural images of exciting, bizarre, and tragic human occurrences"); Paul Brownfield, Are We "Truman?, "L.A. TIMES, June 16,1998 , at F1 (describing the growth in the "reality-as-entertainment" business). 
tertainment. ${ }^{96}$ While they may be entertaining, the stories these shows convey are factual. Elements of news and entertainment thus become inextricably intertwined, making it impossible to draw a distinction that will protect private individuals from the risk of becoming involuntary subjects of "reality" television without impeding First Amendment protections for the press.

There is, to be sure, entertainment value in news. We are amused (and occasionally outraged) by the foibles of public figures. ${ }^{97}$ We are transfixed when the protective screens are ignominiously stripped away from heretofore mighty wizards (or presidents) of $\mathrm{Oz}^{98}$ And we are delighted, touched, and captivated by stories that reveal the alltoo-human qualities of media personalities who live in far away and exotic places like New York, Hollywood, or Washington, D.C. ${ }^{99}$ This is in part why most Americans begin their day reading a newspaper or magazine, or watching or listening to one of a myriad of morning news programs broadcast daily on television and radio. ${ }^{100}$ This does not, however, signify a grave new threat to individual privacy, demanding the invention (or re-invention) of new protective tort laws. In fact, the merger of news and entertainment is not new at all; rather, the entertainment that permeates modern news follows a long tradition in American journalism.

When Charles Dickens's Martin Chuzzlewit stepped off a steamer from England in the 1840s, the cries of dockside paperboys assaulted him: “'Here's this morning's New York Sewer!' cried one. 'Here's this morning's New York Stabber! Here's the New York Family Spy! Here's the New York Private Listener! Here's the New York Peeper! Here's the New York Plunderer! Here's the New York Keyhole Reporter! Here's the New York Rowdy Journal!" " with the scene. Shortly before writing this book, he traveled to the United States where he experienced first-hand the unbounded free-

${ }^{96}$ See Brownfield, supra note 95 , at F1 (characterizing television programs like Cops and MTV's Real World as part of "pop culture").

${ }^{97}$ During his four years as Vice President, for example, Dan Quayle provided latenight television comedians with an almost daily dose of fresh fodder.

${ }_{93}$ Few public figures have been so exposed as Bill Clinton while the Monica Lewinsky scandal and his subsequent impeachment captivated the nation.

${ }_{99}$ For example, Michael J. Fox's disclosure that he was suffering from Parkinson's disease was a sobering revelation. See Michael Barron, Public Lives, N.Y. TIMES, Nov. 26, 1998, at B2 (reporting that Fox's agent acknowledged that the star has the disease).

${ }^{100}$ See LOIS G. Forer, A CHILIING EFFEcT: THE MOUNIING THREAT OF LIBEL AND INVASION OF PRIVACY ACTIONS TO THE FIRST AMENDMENT 162 (1987) (describing Americans' insatiable demand for news).

101 ChaRles Dickens, MARTIN CHUZZLEwTr 318 (Penguin Books 1975) (1843). 
dom of the American press expressing its more salacious personality. ${ }^{102}$ The progeny of this freedom, represented by the National Enquirer and its ilk, clearly are not new phenomena. ${ }^{103}$ Indeed, tabloid journalism, offering an endless stream of embarrassing truths and $a b-$ surd tales, has enjoyed a long and profitable history in America. ${ }^{104}$

With this history comes the mixing of news and entertainment,

${ }^{102}$ P.N. Furbank, Introduction, in DickENS, supra note 101, at 11.

${ }^{103}$ See EMERY \& EMERY, supra note 2, at 284-89 (discussing sensationalist journalism in the early twentieth century). The so-called "supermarket tabloids," such as The $\mathrm{Na}$ tional Enquirer and Star, offer focused coverage of scandals, conspiracies, and celebrities. See id. The Enquirer, however, impelled by sliding circulation and earnings, if not the chastening of plaintiffs, has lately embarked on a program to improve its own image. See Steve Coz, Enquirer's Bold New Look, NAT'L ENQUIRER, Oct. 12, 1999, at 3 (describing measures taken by the tabloid to improve itself "for the New Millenium"); Matthew Rose, Reincarnated Supermarket Tabloid Kills Elvis!, WALl ST. J., Oct. 1, 1999, at B1 (describing the popular tabloid's efforts to retool its image). The Enquirer's story list now more than ever appears slanted toward hyping Hollywood celebrities. See Rose, supra (citing the new "bigger focus on celebrity features"). See, e.g., Dixie Chick Has a New Rooster in Her Henhouse, NAT'L ENQUIRER, Oct. 12, 1999, at 5 (discussing a country star's desire to divorce her husband and marry her boyfriend); Sexy Salma's Got a New Beau, NAT'L ENQUIRER, Oct. 12, 1999, at 5 (discussing actress Salma Hayek's break-up with a boyfriend).

${ }^{104}$ The American tradition of scandal-mongering long predates Dickens. Puritan clergy were scandalized in the 1680 s by colonial printer Benjamin Harris, who reported on the French King's immoral activities with the prince's wife. See EMERY \&c EMERY, supra note 2, at 23. In Jacksonian America, newspapers regularly published articles detailing the sex lives of politicians, including the President himself, often with total disregard for the articles' truth or falsity. See Adam Goodheart, Sleaze Joumalism? It's an Old Siory, N.Y. TIMES, Feb. 20, 1998, at A17. Rather than criticizing this practice, however, Alexis de Tocqueville wrote after touring the United States in 1831 and 1832 that " $[t]$ o suppose that [newspapers] only serve to protect freedom would be to diminish their importance: they maintain civilization." ALEXIS DE TOCQUEVILLE, 2 DEMOCRACY IN AMERICA 111 (Phillips Bradley ed. \& Henry Reeve et al. trans., Vintage Books 1945) (1835).

Modern proponents of expanded privacy conveniently ignore this tradition. Professor McClurg, for example, decried the "titillations offered to readers about Bill Clinton in $1992^{\prime \prime}$ as evidence that attacks by the press are getting worse. McClurg, supra note 17, at 1011. He suggested that " $[\mathrm{t}]$ o measure societal changes in civility since the time of Warren and Brandeis, try to picture an editor in the 1890 s giving the green light to an article detailing the sexual prowess of a United States president." Id. "It is ludicrous," he added, "to imagine reading ... that Grover Cleveland performed oral sex "like a champ." Id. On the contrary, however, there is no need to imagine such a scenario: during his campaign for President in 1884, Cleveland was charged with the paternity of an illegitimate son by his hometown paper, and during his presidency was dogged by reporters at his wedding and on his honeymoon. See FRANK LUTHER MOTT, AMERICAN JOURNAIISM: A HISTORY: 1690-1960, at 510-11 (3d ed. 1962). Not surprisingly, a contemporary commentator called the reports on Cleveland "an impertinent intrusion into private life without parallel in the history of journalism." Id. at $511 \mathrm{n} .21$ (quoting an article in JOURNAIIST, June 5, 1886). Evidently, little has changed about the media or our attitudes toward it in the succeeding 100 years. 
perhaps an unavoidable consequence of unleashing the press to compete in a free market. ${ }^{105}$ William Randolph Hearst, a master of the market, understood this fact when he proclaimed over a century ago that “[i]t is the Journal's policy to engage brains as well as to get the news, for the public is even more fond of entertainment than it is of information." ${ }^{106}$ Hearst, his contemporary Joseph Pulitzer, and later, Rupert Murdoch all applied this principle and built media empires based in part on America's insatiable hunger for entertaining (and lurid) gossip. ${ }^{107}$ Unfortunately, the resulting product often offends our sense of propriety-as much in the 1840 s or 1890 s as today. ${ }^{108}$ Nonetheless, while overly sensationalized headlines can have undesirable consequences, ${ }^{109}$ and in-your-face reporting and the proliferation of reality-based television may further blur the line between news and entertainment, they hardly suggest the sudden demise of individual privacy. Consequently, attempts to brand the merger of news and entertainment as novel are misleading and fail to justify the restrictions that some would impose on press freedoms by allowing liability for intrusion claims. ${ }^{110}$

${ }^{105}$ See ROSEN, supra note 4, at 31-32 (noting the corresponding rise of "tabloid television" as news executives, answering to Wall Street, focus increasingly on bottom line profits).

${ }^{106}$ Hearst made this pronouncement in a "first birthday" editorial in the November 8, 1896 edition of his New York Joumal. See W.A. SWANBERG, CITIZEN HEARST 90 (1961) (quoting N.Y. JouRNAI, Nov. 8, 1896).

${ }^{107}$ See Ken Gormley, One Hundred Years of Privagy, 1992 WIS. L. REv. 1335, 1351 ("The trademark of Pulitzer, Hearst and others who followed in their footsteps was to emphasize the curious, dramatic and unusual ...."). Hearst, Pulitzer, and Murdoch learned early that, as long as consumers continue to demand stories detailing the intimate facts of their neighbors' lives, some elements of the press will strive to deliver. Ultimately, in choosing what to read, watch, and hear, it is the public's discerning taste that sets the boundaries of acceptable content.

${ }_{108}$ For example, there was widespread public outcry after television stations broke away from regular daytime programming in order to broadcast a live police-chase that culminated with a man's suicide. SeeJames Sterngold, After a Suicide, Questions on Lurid TV News, N.Y. TIMES, May 2, 1998, at Al (noting "calls to the stations from angry parents" in the aftermath of the event).

${ }^{109}$ Yellow journalism in late nineteenth-century New York promoted American involvement in a war against Spain. See WALTER LAFEBER, THE AMERICAN AGE: UNITED STATES FOREIGN POLICY AT HOME AND ABROAD SINCE 1750186 (1989). But see SCHUDSON, supra note 9, at 23 (claiming that the impact of the "yellow" press on the Spanish-American War is a legend sown by revisionist historians).

${ }^{110}$ Although the focus here is admittedly on news media, it is important not to lose sight of the issue's larger context. Beyond the clamor against increasingly entertainment-oriented news programs, one thing remains clear: the communicative strength of drama, humor, and the other aspects of entertainment and salesmanship has been the hallmark of all great communication-from The Bible to Seinfeld. We remember 


\section{B. Private Facts: The Story of Nurse Camahan}

Anticipating contemporary critics of the press, Samuel Warren's and Louis Brandeis's disapproval of the perceived convergence of news and entertainment ${ }^{11}$ moved them to write what some have called history's most influential law review article. ${ }^{112}$ Warren, a member of a socially prominent Boston family, was angered when his and his wife's taste for lavish entertainment became the subject of newspaper reports. ${ }^{113}$ Joined by Brandeis, he attacked the press's fixation on gossip, accusing it of "overstepping in every direction the obvious bounds of propriety and of decency. ${ }^{\text {114 }}$ "To satisfy a prurient taste," the article

the phrase "the facts, ma'am, just the facts" because Joe Friday delivered it in the context of one of early television's most entertaining programs, not because the substance of his statement was so compelling. (Joe Friday was a character on the television program Dragnet which originally aired from 1951-1959. See Michael Hayde, Badge 714, The Dragnet Web Site (last modified Aug. 28, 1999) <http://www.badge714.com/ DRAGNET1.htm> (summarizing Dragnet episodes)). Similarly, a classroom teacher is unlikely to impart anything to students unless she succeeds in engaging them in the material. This may require audio and visual aids, personal anecdotes, or simply ebullient enthusiasm, all of which fit a reasonable definition of "entertainment." Indeed, one easily could liken good teaching to hosting the Tonight Show.

The writer Brendan Gill, speaking in Ken Burns's 1998 film biography of Frank Lloyd Wright, punctuated this point. He noted that early in his friendship with the flamboyant Wright he had suggested that "all the great men of our time had been more or less charlatans. Like Picasso, like FDR, there was a quality of charlatanism in them that made them successful with the public." Gill explained that after a moment's discomfort, Wright conceded that "the degree to which he had seemed in the world to be a charlatan boasting and showing off and carrying on was the reason that it was possible then to get his work before the public." Gill added, "Of course, it is the excuse that all charlatans use, but in truth, [Wright] was a great showman, and to be a showman is to be in part a charlatan." Frank Lloyd Wright (PBS television broadcast, Nov. 14, 1998). Good writers, teachers, and even architects recognize that a bland recitation of facts is unlikely to attract attention, much less to convey information. Nor, as most news directors have further learned, is it likely to draw viewers or sell newspapers. Ultimately, entertainment is the essence of effective speech, and efforts to separate it from news are as impractical as they are likely unconstitutional.

111 See Gormley, supra note 107, at 1349 (citing "the newspaper gossip which Warren and Brandeis chided").

${ }^{112}$ See Prosser, supra note 26, at 383 (observing that the article "has come to be regarded as the outstanding example of the influence of legal periodicals upon the American law"). For the actual article, see Warren \& Brandeis, supra note 26.

113 See ADAM CARLYLE BRECKENRIDGe, ThE Right TO PRIVACY 132 (1970) (providing a brief account of the generally accepted view of events leading to the Warren and Brandeis article); Prosser, supra note 26, at 383 (describing the circumstances provoking Warren's annoyance); see also Zimmerman, supra note 45, at 295 (explaining that in the 1890 s, proper Bostonians considered it a disgrace to have their name printed in the newspaper).

${ }^{114}$ Warren \& Brandeis, supra note 26, at 196. Warren and Brandeis were responding in part to "yellow journalism," which was the hallmark of publishers like Hearst and Pulitzer. See EMERY \& EMERY, supra note 2, at 94. Yellow journalism emerged amidst 
continued, "the details of sexual relations are spread broadcast in the columns of the daily papers." ${ }^{115}$

Building on what Warren and Brandeis termed "the right to be let alone, ${ }^{n 116}$ William Prosser articulated the common modern approach to privacy law in $1960 .^{117}$ He divided tort actions for invasion of privacy into four distinct claims: (1) public disclosure of private facts; ${ }^{118}$ (2) intrusion into private places, conversations, or other matters; ${ }^{119}$ (3) presentation of the plaintiff in a false light; ${ }^{120}$ and (4) appropriation of images or personality. ${ }^{121}$

In application, the false light tort is but a twist on libel law that has seldom drawn much serious attention from plaintiffs or courts, ${ }^{122}$ and, in any event, is subject to the same First Amendment-based protective rules that limit libel. ${ }^{123}$ The appropriation tort is important primarily

an explosion of mass media outlets in the latter half of the nineteenth century. Between 1880 and 1890, 625 new daily newspapers emerged-the largest ten-year increase in American history. See DON R. PEMBER, PRIVACY AND THE PRESS: THE LAW, THE MASS MEDIA, AND THE FIRST AMENDMENT 10 (1972). Similarly, the number of weekly papers increased from 7811 to 13,559 and the number of new books published annually jumped from 2076 to 4559 . See id. Meanwhile, between 1850 and 1890 , circulation for daily papers increased $1100 \%$, from 758,000 in 1850 to $8,387,000$ in 1890 . See id. at 10-11. This growth was particularly significant in large metropolitan areas like New York, Philadelphia, Chicago, Cleveland, Boston, and San Francisco. See id. at 11. Given this proliferation of news providers, competition-and the demand for shocking, attention-grabbing headlines-was necessarily fierce.

${ }_{115}$ Warren \& Brandeis, supra note 26, at 196. It should be noted that Warren's name actually appeared in the Boston paper only infrequently. See Gormley, supra note 107, at 1349 ("The Saturday Evening Gazette-generally credited with infuriating Warren-only mentioned his name twice between the years 1883 and $1890 \ldots$..."). One commentator observed that "Warren and Brandeis were ... guilty of verbal overkill. Their characterization of the Boston press was less than accurate." PEMBER, supra note 114, at 41; see also James H. Barron, Warren and Brandeis, The Right to Privacy, 4 Harv. L. Rev. 193 (1890): Demystifying a Landmark Citation, 13 SuFfolk U. L. REv. 875, 916 (1979) (suggesting that Warren's hostility to the report derived instead from his narrow conception of news).

${ }^{116}$ Warren \& Brandeis, supra note 26, at 193. Warren and Brandeis borrowed the phrase from Judge Cooley's treatise on torts, published two years earlier. See Prosser, supra note 26, at 389 (citing THOMAS M. COOLEX, TORTS 29 (2d ed. 1888)).

${ }^{117}$ See Prosser, supra note 26.

118 See id. at 392-98.

119 See id. at 389-92.

${ }^{120}$ See id. at $398-402$.

121 See id. at 402-07.

122 See Diane Leenheer Zimmerman, False Light Invasion of Privacy: The Light That Failed, 64 N.Y.U. L. REV. 364, 367-68 (1989) (noting the general reluctance of courts to apply the false light doctrine).

${ }_{123}$ See Time, Inc. v. Hill, 385 U.S. 374, 390 (1967) (applying the constitutional doctrine established in New York Times v. Sullivan, 376 U.S. 254 (1964), requiring either deliberate or reckless falsity in a claim for defamation, to the question of false light 
in intellectual property disputes, and plaintiffs rarely rely on it as a hammer to punish unpopular speech. ${ }^{124}$ The first two Prosser categories, however, if not carefully circumscribed by the First Amendment, present serious threats to free speech and constituted the basis of the claims in Shulman.

The California Supreme Court began its analysis in Shulman ${ }^{125}$ with the publication of private facts claim, ${ }^{126}$ focussing its discussion on the question of newsworthiness. ${ }^{127}$ The court correctly adopted the wellestablished standard put forth by the producers that "dissemination of truthful, newsworthy material is not actionable as a publication of private facts. ${ }^{n 128}$ It then tackled the question of whether a story about the

privacy).

${ }^{124}$ See Zacchini v. Scripps-Howard Broad. Co., 433 U.S. 562, 573 (1977) (noting that the State's interest in protecting against misappropriation "is closely analogous to the goals of patent and copyright law, focusing on the right of the individual to reap the reward of his endeavors and having little to do with protecting feelings or reputation").

${ }^{125}$ Justice Werdegar's plurality opinion in Shulman actually spoke for two separate majorities. The opinion was joined in full by Chief Justice George and Justice Kennard (although Justice Kennard did write a separate concurrence joined by Justice Mosk). See Shulman v. Group W Prods., 955 P.2d 469, 498 (Cal. 1998) (noting the concurrence of George, C.J., and Kennard, J.). Justice Chin, in an opinion joined by Justice Mosk, however, concurred that " $[t]$ he newsworthy nature of the disclosure absolutely precludes plaintiffs' recovery" on the private facts claim but dissented "from the plurality's holding that plaintiffs' 'intrusion' cause of action should be remanded for trial." Id. at 501 (Chin, J., concurring in part and dissenting in part, joined by Mosk, J.). Justice Brown, in an opinion joined by Justice Baxter, on the other hand, concurred "that summary judgment should not have been granted as to the cause of action for intrusion" but dissented "from the conclusion that summary judgment was proper as to plaintiff Ruth Shulman's cause of action for publication of facts." Id. at 502 (Brown, J., concurring in part and dissenting in part, joined by Baxter, J.).

${ }^{126}$ The court identified four elements of the private facts claim: “"(1) public disclosure (2) of a private fact (3) which would be offensive and objectionable to the reasonable person and (4) which is not of legitimate public concern." Shulman, 955 P.2d at 478 (quoting Diaz v. Oakland Tribune, Inc., 188 Cal. Rptr. 762, 768 (Ct. App. 1983)); $c f$. RESTATEMENT (SECOND) OF TORTS, § 652D (1977) (offering a similar formulation).

${ }^{127}$ See Shulman, 955 P.2d at 478 ("The element critical to this case is the presence or absence of legitimate public interest, i.e., newsworthiness, in the facts disclosed.").

${ }^{128}$ Id. at 479. In 1969, the California Supreme Court stated:

With the expansion of the common law's protection of an individual's privacy, came a concomitant recognition of an equally important, and constitutionally enshrined, competing interest of the public in information of newsworthy matters. Sensitive to the privacy tort's potential encroachment on the freedoms of speech and the press, our courts have recognized a broad privilege cloaking the truthful publication of all newsworthy matters.

Kapellas v. Kofman, 459 P.2d 912, 922 (Cal. 1969) (footnote and citations omitted).

The Shulman court went on to examine its earlier decision in Briscoe v. Reader's Digest Association, Inc., 483 P.2d 34 (Cal. 1971), and reaffirmed its holding that "newswor- 
Shulmans' rescue was in fact newsworthy. ${ }^{129}$

Recognizing that an analysis of newsworthiness involves at least a limited "normative assessment" of subject matter, the court first sought to evaluate the "social value" of the story. ${ }^{130}$ Next, to judge the reasonableness of the alleged privacy invasion, the court undertook a determination of "the extent to which the plaintiff[s] played an important role in public events." ${ }^{\text {"131 }}$ Since neither Shulman nor her son were public figures, ${ }^{132}$ the court also required that "a logical nexus ex-

thiness is a complete bar against liability for publication of truthful private facts." Shulman, 955 P.2d at 483 n.6. See generally Richard F. Hixson, Privacy IN A PUBLIC SOCIETY: HUMAN RIGHTS IN CONFLICT 161 (1987) (discussing the media's frequent reliance on the newsworthiness defense).

${ }^{129}$ See Shulman, 955 P.2d at 479-86 (analyzing relevant constitutional and state standards for determining "newsworthiness"). The difficulty of establishing a constitutionally acceptable distinction between what is and is not news is not lost on the courts or commentators. See, e.g., Cox Broad. Corp. v. Cohn, 420 U.S. 469, $494-97$ (1975) (holding that despite the painful nature of such revelations, a state may not prohibit publication of the names of rape victims as news so long as the names are otherwise available in the public record). The question is addressed by Harper, James, and Gray in their treatise on the law of torts. They explain:

If a person is in an unusual accident and finds his picture in the paper the next morning, perhaps he has no legal complaint even though he is the most inconspicuous of private citizens. If one is the victim of a crime, or is accused of having committed it, his privacy is not invaded by the publication of such matters. On the other hand, a woman may well complain if an X-ray picture of her malformed pelvis is shown in a syndicated newspaper column without her consent, notwithstanding public curiosity.

2 FOWLER V. HARPER ET AL., THE LAW OF TORTS $651-52$ (2d ed. 1986) (citations omitted).

${ }^{130}$ Shulman, 955 P.2d at 483 . The newsworthiness defense inevitably is circular, as the press also decides what is news. See Comment, The Right of Privacy: Normative Descriplive Confusion in the Defense of Newsworthiness, 30 U. CHI. L. REv. 722, 725 (1963) (giving a detailed account of the circularity problem). Thus, the court necessarily must exercise some editorial judgement of its own. Compare Haynes v. Alfred A. Knopf, Inc., 8 F.3d 1222, 1233 (7th Cir. 1993) (finding no invasion of privacy for a man whose life is the subject of a book about the black migration from the rural south, terming the author's treatment of a painful period in the plaintiff's life as "decorous and restrained"), with Virgil v. Time, Inc., 527 F.2d 1122, 1129 (9th Cir. 1975) (questioning whether a story about the bizarre habits of a prominent surfer was really news or rather "morbid and sensational prying"). The court should exercise such judgment cautiously, however, and show great deference to media professionals.

131 Shulman, 955 P.2d at 484. The court observed that

Some reasonable proportion is ... to be maintained between the events or activity that makes the individual a public figure and the private facts to which publicity is given. Revelations that may properly be made concerning a murderer or the President of the United States would not be privileged if they were to be made concerning one who is merely injured in an automobile accident.

Id. (quoting RESTATEMENT (SECOND) OF TORTS $\S 652 \mathrm{D} \mathrm{cmt.} \mathrm{h} \mathrm{(1977)).}$

${ }_{132}$ Prosser addressed the concern for private individuals who are inadvertently 
ist between the complaining individual [s] and the matter of legitimate public interest."

The court rightly determined that on all points the facts in this case favored the producers. First, it held that an automobile accident on a public highway and the associated response of public emergency services are reasonably in the public interest and that stories related to these events have clear social value. ${ }^{134}$ Second, the plaintiffs' involvement in the accident drew them into the public eye. ${ }^{135}$ Third, the court concluded that the private facts revealed by the story all reasonably related to the newsworthy event. ${ }^{136}$ Thus, the court concluded that the story on the Shulmans' accident was newsworthy and the First Amendment, at least as it concerned this claim, protected the producers' actions. ${ }^{137}$

In its analysis, the court made an important distinction when it recognized that the focus of the story was not Ruth Shulman, but rather the heroic efforts of Nurse Carnahan and the other members of the rescue team. ${ }^{138}$ The danger presented by the leaking gasoline and the threat of explosion and fire to Carnahan as she worked under the car, for example, were dominant themes throughout the report. ${ }^{139}$ Similarly, the narrator focused on the difficulties of the extrication, and most of the audio heard during the segment is dialogue between rescue workers as they assessed the many logistical problems confronting them. In its opinion the court noted:

The rescue and medical treatment of accident victims is also of legitimate concern to much of the public, involving as it does a critical service that any member of the public may someday need. The story of Ruth's difficult extrication from the crushed car, the medical attention given

caught in the public spotlight. He observed that "[w] hat is called for, in short, is some logical connection between the plaintiff and the matter of public interest." Prosser, supra note 26 , at 414 .

${ }^{135}$ Shulman, 955 P.2d at 484 (citing Campbell v. Seabury Press, 614 F.2d 395, 397 (5th Cir. 1980)).

${ }^{134}$ See id. at 488 (holding that automobile accidents as well as rescue and medical treatment are by their nature of public interest).

${ }^{135}$ See id. (finding that the specific story of Shulman's "difficult extrication" was of "particular public interest").

${ }^{136}$ The court held that the facts presented in the program, though perhaps not all necessary, were relevant to the telling of the story. It emphasized that relevance, not "necessity," was the applicable standard for private facts. Seeid.

${ }^{137}$ See id. at 488-89 (affirming summary judgment in favor of the defendant on plaintiffs' private facts claim).

${ }^{13 s} S_{e e} i d$. at 488 ("One of the dramatic and interesting aspects of the story as a whole is its focus on flight nurse Carnahan.").

${ }^{199}$ See supra text accompanying notes 55-89 (summarizing the broadcast). 
her at the scene, and her evacuation by helicopter was of particular interest because it highlighted some of the challenges facing emergency workers dealing with serious accidents.

This larger story, into which Shulman unfortunately was drawn, was of significant social interest and the producers' efforts to tell that story were protected by the First Amendment.

The focus on Carnahan as a subject of legitimate public interest does not suggest that Shulman's role in the program was immaterial or that the press may simply ignore her personal privacy. Her conversations with Carnahan, however, were used primarily to illustrate an important facet of a rescue worker's job. The court observed that "this type of emergency care requires not only medical knowledge, concentration and courage, but an ability to talk and listen to severely traumatized patients. ${ }^{n 11}$ The recorded conversations were a poignant illustration of this fact. The court explained that "[o]ne of the challenges Carnahan faces in assisting Ruth is the confusion, pain and fear that Ruth understandably feels in the aftermath of the accident. ${ }^{\text {142 }}$ Furthermore, the information revealed about Shulman was generic in nature: the program revealed no intensely personal or identifying private facts. ${ }^{143}$ Consequently, the court concluded, the video of Shulman's injured physical state, which the court emphasized "was not luridly shown," and the audio revealing her "disorientation and despair" were relevant and newsworthy as a matter of law. ${ }^{144}$

${ }^{140}$ Shulman, 955 P.2d at 488.

${ }^{141}$ Id.

${ }^{142}$ Id

143 See supra note 89 (quoting the Shulman court's description of the visual portrayal of Shulman during the broadcast). Had her medical history or other personal information been disclosed, the outcome on this claim might (rightfully) have been quite different. Courts in California and elsewhere have consistently recognized that disclosure of such irrevelant private facts is essential to a private facts claim. See Briscoe v. Reader's Digest Ass'n, 483 P.2d 34, 40 (Cal. 1971) (finding that the identity of the plaintiff as the perpetrator of an eleven-year-old truck hijacking was not relevant to a general article about similar criminal acts); Gill v. Curtis Publ'g Co., 239 P.2d 630, 63435 (Cal. 1952) (finding that an otherwise unrelated picture of the plaintiffs in an affectionate pose was not relevant to an article about love); Diaz v. Oakland Tribune, Inc., 188 Cal. Rptr. 762, 772-73 (Ct. App. 1983) (holding that the revelation that the plaintiff was a transsexual in an article about her election to the student-body presidency at a local junior college was not newsworthy as a matter of law); Green v. Chicago Tribune, 675 N.E.2d 249, 255-56 (Ill. App. Ct. 1996) (holding that a jury could find that the words of a grieving mother, spoken over the body of her slain son at his funeral, were not relevant to a story about his death).

${ }_{144}$ See Shulman, 955 P.2d at $488-89$ (concluding that the video footage of Shulman was an essential part of a newsworthy story); see also id. at 501 (Chin, J., concurring in part and dissenting in part) ('Defendants' apparent motive in undertaking the sup- 
By its holding, the court implied that the convergence of news and entertainment did not deprive the broadcast of First Amendment protections. It found that, despite the program's entertainment value, the underlying news story was of legitimate public interest and not an unwarranted publication of private facts. ${ }^{145}$ The court's analysis on this issue was sound and offered appropriate protection to press freedoms.

\section{Intrusion: The Plight of Ruth Shulman}

The court's analysis of the Shulmans' intrusion claim, however, is more problematic. Courts have long regarded the private facts tort as the chief means for reconciling conflicts between press freedoms and individual privacy. In the words of commentators, it is the "mass communication tort of privacy;" ${ }^{146}$ the others "are offspring from the wrong side of the blanket, scions of meretricious liaisons between privacy and the torts of trespass, defamation, and ... trade-mark infringement."147 Ignoring this tradition, however, the Shulman court shifted its focus from the private facts claim and allowed the claim for intrusion. In its analysis of this alternative cause of action, the court appeared to forget all the sound reasoning that underlay its justification for denying the private facts claim and opened the door to new, harmful attacks on First Amendment freedoms.

In its analysis, the court adopted the Restatement's standard requiring " $(1)$ intrusion into a private place, conversation or matter, (2) in a manner highly offensive to a reasonable person. ${ }^{118}$ It then considered three possible intrusions to satisfy the claim: the videotaping of footage at the accident scene, the videotaping of footage aboard

posed privacy invasion was a reasonable and nonmalicious one: to obtain an accurate depiction of the rescue efforts from start to finish. The event was newsworthy, and the ultimate broadcast was both dramatic and educational, rather than tawdry or embarrassing.").

${ }^{145}$ See id. at $488-89$ ("The challenged material was substantially relevant to the newsworthy subject matter of the broadcast.").

${ }^{146}$ Kalven, supra note 26, at 333.

147 Dorsey D. Ellis Jr., Damages and the Privacy Tort: Sketching a "Legal Profile," 64 IOWA L. REv. 1111, 1111 (1979) (footnotes omitted). Theodore Glasser further noted that " [i]n short, embarrassing facts as news remain the principal privacy controversy, an issue of Constitutional proportion insofar as 'news' falls within the purview of the First Amendment." Theodore L. Glasser, Resolving the Press-Privacy Conflict: Approaches to the Newsworthiness Defense, in PRIVACY AND PUBLICITY: READINGS FROM 2 COMMUNICATIONS AND THE LAW 15, 16 (Theodore R. Kupferman ed., 1990).

${ }^{148}$ Shulman, 955 P.2d at 490 (citing RESTATEMENT (SECOND) OF TORTS §652B (1977)). See also Miller v. NBC, 232 Cal. Rptr. 668, 678 (Ct. App. 1986) (adopting the RESTATEMENT's formulation). 
the helicopter, and the recording of conversations between Shulman and Carnahan both at the accident scene and on the flight to the hospital. ${ }^{149}$ The court appropriately determined that the plaintiffs had no reasonable expectation of privacy that would protect against videotaping at the accident scene. ${ }^{150}$ The court erred, however, in upholding the cause of action on the other two alleged intrusions.

The court found an "objectively reasonable expectation of privacy" during the flight to the hospital by equating the interior of the helicopter to an ambulance or hospital room. ${ }^{151}$ Its reasoning here, however, is dubious. Although California common law recognizes an expectation of privacy in a hospital room, ${ }^{152}$ the cases cited by the court are not persuasive when applied to the facts of Shulman.

The court first cited Noble v. Sears, Roebuck $\mathcal{E}$ Co., a California Court of Appeal decision concerning the actions of private investigators. ${ }^{153}$ In Noble, investigators had entered the plaintiff's hospital room in order to gain information about the plaintiff's unrelated personal injury action against Sears. ${ }^{154}$ First Amendment considerations as well as public interest matters that might meet a reasonable newsworthiness test were entirely absent from the Noble case. In spite of the fact that the interests of the press played no part in the Noble decision, the Shulman court applied the Noble rule. ${ }^{155}$ The Shulman decision thus provided no justification or guidelines for limiting press freedoms in a hospital-like setting. ${ }^{156}$

149 See Shulman, 955 P.2d. at 490-91.

${ }^{150}$ See id. at 490 (reasoning that "for journalists to attend and record the scenes of accidents and rescues is in no way unusual or unexpected").

${ }^{151}$ See id. at 490-91 (citing California case law protecting privacy in hospital rooms and accepting the observation of the Court of Appeal that " $[\mathrm{i}] \mathrm{t}$ is neither the custom nor the habit of our society that any member of the public at large or its media representatives may hitch a ride in an ambulance and ogle as paramedics care for an injured stranger"). Interestingly, however, it was not the ogling of the idly curious that led to the Shulmans' claim, but rather the videotaping of the accident and rescue in order to make a more compelling account of an event the court itself conceded to be of significant public interest.

${ }^{152}$ See Noble v. Sears, Roebuck \& Co., 109 Cal. Rptr. 269, 272-73 (Ct. App. 1973) (holding that an investigator violated the plaintiff's right to privacy by intruding on her "exclusive right of occupancy of her hospital room" if such right can be proven by the evidence at trial).

${ }^{153} I d$.

${ }^{154}$ See id. at 657 (explaining the initial action brought by the plaintiff for alleged injuries she had suffered while shopping at Sears).

${ }_{155}$ See Shulman, 955 P.2d at 490 (citing Noble to support the proposition that "no law or custom permit[s] the press to ride in ambulances or enter hospital rooms without the patient's consent").

${ }^{156}$ See id. (applying the Noble rule without distinguishing its holding despite the 
Next, the court cited Miller v. National Broadcasting $\mathrm{Co}^{157}$ In this case, the California Court of Appeal allowed a claim for breach of privacy by intrusion after an NBC camera crew accompanied paramedics into the plaintiff's private residence without permission to videotape rescue efforts. ${ }^{158}$ A reporter trespassing in a private residence, however, clearly is distinguishable from a reporter's presence in a public space or aboard a vehicle with the express permission of the vehicle's owner.

The precedents of Noble and Miller do not establish that courts must afford individuals involved in newsworthy events that occur in public the same degree of privacy protection as the plaintiffs in those cases. ${ }^{159}$ The critical factors that make privacy important in a hospital room-access to medical records, discussions with physicians regarding personal medical decisions, and time with family ${ }^{160}$-are absent in an ambulance or rescue helicopter. ${ }^{161}$ Moreover, the degree of privacy

lack of a First Amendment issue). The implications for First Amendment freedoms that arise when plaintiffs challenge actions by the press demand that the court give greater scrutiny. See, e.g., New York Times v. United States, 403 U.S. 713, 725-26 (1971) (Brennan, J., concurring) (emphasizing the paramount status of the First Amendment).

${ }^{157} 232$ Cal. Rptr. 668 (Ct. App. 1986).

${ }^{158}$ See id. at 683 ("One seeking emergency medical attention does not thereby 'open-the-door' for persons without any clearly identifiable and justifiable official reason who may wish to enter the premises where the medical aid is being administered.").

159 Nevertheless, some interpret the decision in Shulman to suggest the existence of an unprecedented zone of "public privacy." See Maura Dolan, News Media Ruled Liable for Undue Intrusion, L.A. Times, June 2, 1998, at A1 (quoting Shulman's attorney, Antony Stuart, who asserted that "[i]t has now been affirmed that the right to privacy exists in public places"). Prior to Shulman, Professor McClurg argued that modern technology demanded the recognition of such an expanded privacy right. See McClurg, supra note 17, at 990-91 (arguing that tort law governing privacy intrusion is not suited for a "modern technological society").

${ }^{160}$ See, e.g., Barber v. Time, Inc., 159 S.W.2d 291, 295 (Mo. 1942) ("Certainly if there is any right of privacy at all, it should include the right to obtain medical treatment at home or in a hospital ... without personal publicity.").

${ }^{161}$ Freedom of choice factors may further distinguish hospital rooms from rescue vehicles. Arguably, in most cases, patients have some freedom to choose their hospital and doctor. Accident victims, however, are not given similar choice among ambulance services nor are they allowed to pre-select their EMTs. Consequently, the degree of accountability to consumers for such services is sharply reduced. This is precisely the sort of watchdog role to which the press is suited, but it is compromised if performance of that role exposes publishers and broadcasters to liability from unwitting subjects.

The court's decision in Shulman, when applied to a hospital room, does not foreclose any public oversight of the hospital itself; in accordance with long established case law, it simply permits the patient the right to control access to a particular room. See, e.g., Barber, 159 S.W.2d. at 295 (asserting a right to privacy in hospitals). The decision does, however, preclude oversight of the emergency response system because 
one can reasonably expect during a medical emergency in one's own home is quite different from what one can expect after an automobile accident along the side of a major interstate highway. Consequently, the Shulman court's leap to expose the producers to liability for the sixty seconds of helicopter footage in a nine-minute news program was unjustified. It opens the door to civil claims that threaten to chill important press freedoms.

In addition to misapplying Noble and Miller, the court erred in finding a reasonable expectation of privacy in Shulman's conversations with rescue personnel. The court reasoned that the use of a portable microphone attached to Carnahan could be deemed an offensive intrusion. ${ }^{162}$ Earlier in its opinion, the court defended the investigative report's newsworthiness ${ }^{163}$ and the public interest in hearing and seeing a rescue worker's ability to comfort and reassure trauma patients. ${ }^{164}$ Yet, here it held that the device used to capture this element might constitute a tortious intrusion on personal privacy. ${ }^{165}$ These two holdings are blatantly incongruent.

An examination of the court's rationale shows that the presence of a microphone had an inexplicable impact on its analysis of the intrusion claim. Although the court praised the investigative style of the program while rejecting a private facts claim, ${ }^{166}$ it seemed to take a far more sinister view of the producers' motives when analyzing the claim

permission is rarely, if ever, attainable from victims in need of emergency services. Put bluntly, while the presence of a reporter riding along with me in an ambulance after a serious accident resulting in severe trauma may at first seem highly objectionable, I am more than willing to accept her presence if it will help ensure the highest quality of care.

${ }^{162}$ See Shulman, 955 P.2d at 491 (“[B]y placing a microphone on Carnahan's person... defendants may have listened in on conversations the parties could reasonably have expected to be private.").

${ }^{163}$ See supra notes $134-37$ and accompanying text (describing the court's finding of newsworthiness).

${ }^{16 t}$ See Shulman, 955 P.2d at 488 (finding a public interest in the report's "highlight[ing] ... of the challenges facing emergency workers dealing with serious accidents").

165 This is particularly troubling in light of the odd contortions the court is willing to undertake in order to find an expectation of privacy along the side of an interstate highway equivalent to the expectation in one's own home. See Shulman, 955 P.2d at 491 ('The rescue did not take place 'on a heavily traveled highway,' as the Court of Appeal stated, but in a ditch many yards from and below the rural superhighway ...."). In a footnote, the court disputes the Court of Appeal's finding of a "crowd of onlookers peering down at the rescue scene" who might have overheard conversations between Shulman and Carnahan. Id. at 491 n.13.

${ }^{166}$ See supra notes $138-40$ and accompanying text (describing the court's recognition of the story's investigative qualities). 
for intrusion. The fact that the defendant reported conversations between Shulman and Carnahan did not seem to bother the court. Rather, it took offense at the means by which it captured those conversations-with a "bug." Interestingly though, the court conceded that the cameraman "perhaps did not intrude into [the] zone of privacy merely by being present at a place where he could hear such conversations with unaided ears. ${ }^{167}$ Hypothetically, then, had Cooke recorded the conversation with written notes (evoking the image of a scrappy beat reporter with spiral notepad in hand) and published them in a newspaper article, Shulman could not have maintained the cause of action. ${ }^{168}$ By extrapolation, one could argue that it would be legitimate if the defendant had refrained from recording Shulman's actual voice and instead used actors to dub the conversations onto an otherwise silent tape. To put it mildly, this logic is silly. The court's validation of fears of microphones does not make sense given the circumstances of this case. On the contrary, it undercuts the press's ability to report a story about which the court concedes the public has a right to know. ${ }^{169}$ Without evidence of more surreptitious motives or actions by the defendant, using a microphone should not have given rise to a claim for intrusion.

The presence of an unchallenged newspaper article further suggests that the roles of various media technologies figure heavily in the analysis of this case. The court notes early in its opinion that the Shulmans conceded that a local newspaper published an account of

167 Shulman, 955 P.2d at 491.

${ }^{169}$ One can make a strong argument that electronic recording devices do more to protect the personal interests of news subjects by insuring the accuracy of stories. This case itself demonstrates the difficulties of reducing live events to words. Supporters of Shulman's position, for example, cite reports that "Ruth Shulman can be clearly heard on the broadcast tape moaning, asking to be allowed to die and begging to be told it is all a dream" as evidence of the media's offensive intrusion on her personhood. McClurg, supra note 17, at 995 (quoting Gail Diane Cox, Privacy's Frontiers at Issue: Unwilling Subjects of Tabloid TV Are Suing, NAT'L L.J., Dec. 27, 1993, at 1). A review of the actual broadcast, however, reveals that this description grossly overstates what occurred. Shulman is surprisingly quiet given the severity of the accident and the obvious suffering she has endured. Although she did say "I want to die" and asked if she was dreaming, she was hardly "begging." Rather her voice reflects disbelief about what has happened to her. Considering the events in full, she comes across as much more dignified on tape than print descriptions would suggest. See also Emergency Flight Raises Privacy Questions, MEDIA \& THE LAW, Apr. 25, 1997 (suggesting inaccurately that Ruth Shulman, and not her daughter Beth, was driving the car, and reporting that Shulman's parents, and not her children, were victims of the accident).

${ }^{169}$ See supra notes 13445 and accompanying text (describing the court's finding that the story of Nurse Carnahan was of legitimate public interest and had social value). 
the accident ${ }^{170}$ This account, which focused specifically on the victims, as opposed to the incident in general, included Shulman's full name with a description of the accident. ${ }^{171}$ Although there is no evidence that a newswire picked up the story and published it for a national audience, people who knew Shulman personally would be likely to read the local paper. Arguably, this account posed a more serious threat to Shulman's privacy, but the plaintiffs did not file an action against the newspaper publisher. One can only assume that the medium of television was a powerful factor in Shulman's feeling of intrusion. ${ }^{172}$

The glamour that the public attaches to events depicted on television is significant. ${ }^{173}$ In the public conception, television is a home for stars; newspapers, on the other hand, report news. This view is evident in Shulman's testimony. When asked to describe her feelings upon seeing the broadcast, Shulman reported being "shocked, so to speak, that this would be run and I would be exploited, have my privacy invaded, which is what I felt had happened." ${ }^{174}$ She apparently did not feel exploited by the newspaper article-that was news. In her mind, however, the television broadcast was different-it was entertainment. ${ }^{175}$ As her testimony continued, she expressed disappointment with the image the program portrayed. She reported having the impression "that I was kind of talking nonstop, and I remember hear-

${ }^{170}$ See Shulman, 955 P.2d at 477 (acknowledging the undisputed fact "that an account of [the plaintiffs'] accident and rescue appeared in a San Bernardino area newspaper shortly after the rescue and before the broadcast").

If See Six People Injured in Sunday 1-10 Accidents, ReCORD-GazeTte (Banning, Cal.), June 25, 1990, at 1 .

${ }^{172}$ In fairness, visual images can have a more powerful impact than mere words or descriptions. See, e.g., VICKI GOLDBERG, THE POWER OF PHOTOGRAPHY: HOW PHOTOGRAPIIS CHANGED OUR LIVES 7 (1991) ("Photographs have a swifter and more succinct impact than words, an impact that is instantaneous, visceral, and intense."). In the context of this case, however, that difference does not suggest that Shulman was harmed by the television broadcast in a way that is distinct from what could have been caused by the newspaper report.

${ }^{173}$ This phenomenon is not new: in the nineteenth century, drawings published in newspapers, not the articles themselves, were considered the most serious threat to personal privacy. See ScHUDSON, supra note 9, at 88 ("[T] he main source of concern ... centered on newspaper illustrations and straight reporting, not on interviews.").

${ }_{174}$ Shulman, 955 P.2d at 476.

${ }^{175}$ Shulman told reporters that " $[t]$ hey took our family's tragedy and made it into entertainment for the whole country," Gail Diane Cox, Who Gets to Tell, Cash In on, 'Reel'Life Stories?, NAT'L L. J., Oct. 6, 1997, at Al, and that "[t]hey took one of the most tragic moments of my life and made it entertainment for the nation," Dolan, supra note 47 , at $\mathrm{Al}$. 
ing some of the things I said, which were not very pleasant. ${ }^{\text {n176 }}$ Shulman did not appear concerned with the fact that her story became news but rather with the way she looked on television. Her comments at deposition were more expansive:

I think the whole scene was pretty private. It was pretty gruesome, the parts that I saw, my knee sticking out of the car. I certainly did not look my best, and I don't feel it's for the public to see. I was not at my best in what I was thinking and what I was saying and what was being shown, and it's not for the public to see this trauma that I was going through.

What Shulman sought was the ability to control the use of her image on television. An independent press, however, cannot function if the subjects of news stories are able to control their portrayal. A stepby-step account of the televised program published in print, much like the one provided in this Comment, ${ }^{278}$ likely would go unchallenged. Certainly, no court would have upheld such a claim. ${ }^{179}$ The aura of television, however, alters expectations of (or desires for) privacy. ${ }^{180}$ Television and other electronic forums are, of course, different from print media. The First Amendment, however, cannot support a double standard for the treatment of news, especially when most citizens say they rely on broadcast media as their primary source of information. ${ }^{181}$ Purveyors of all media may have an ethical obligation to act responsibly, but the First Amendment limits the extent to which that responsibility may be enforced through the courts or by the government. If government dictates arbitrary boundaries of taste, the limits put on the public's right to know and the restrictions placed on asso-

${ }^{176}$ Shulman, 955 P.2d at 476.

177 Id.

${ }^{178}$ See supra notes 55-88 and accompanying text (summarizing the broadcast).

${ }^{179}$ Shulman's story was considered newsworthy by both the courts, see Shulman, 955 P.2d at 488 (concluding that "the disputed material was newsworthy as a matter of law"), and implicitly by Shulman herself when she chose not to object to the newspaper article.

${ }_{180}$ See, e.g., McClurg, supra note 17, at 1017-25 (describing the threat to privacy posed by technological advances, particularly by television news organizations' encouragement of surreptitious videotaping).

${ }^{181}$ In 1963, the Roper survey of public attitudes towards television found for the first time that more people listed television as a chief source of news than newspapers. See MICFAEL SCHUDSON, DISCOVERING THE NEWS 182 (1978) (summarizing the Roper survey results). By $1974,65 \%$ mentioned television as one of their chief sources of news, while only $47 \%$ mentioned newspapers. See id. Today, according to surveys conducted by the Pew Research Center for the People \& the Press, the average American dedicates 31 minutes a day to watching television news, 17 minutes a day listening to radio news, and only 18 minutes reading a newspaper. See The Pew Research Center for People $\mathcal{E}$ the Press (visited Nov. 7, 1999) <http://www.people-press.org/medsec3.htm>. 
ciated press freedoms come at unacceptably high costs.

\section{More Privacy, Less Liberty}

The impact of the court's decision is twofold. On the one hand, the court affirmed the limits of the private facts tort by refusing to impose liability for the report of a newsworthy story. To this end, the decision further clarified the powerful role of editors, protected by the First Amendment, in deciding what constitutes news, additional entertainment value notwithstanding. On the other hand, the decision greatly expanded the scope of the intrusion tort by allowing potential liability for a reporter's newsgathering techniques. In effect, the court allowed Shulman to attack newsgathering when the facts would not allow her to attack an editor's judgment of newsworthiness. The result for press freedoms is no less disastrous. Limiting access to information cuts off the press's ability to tell a story. First Amendment tenets cannot tolerate such a result.

Particularly troubling in this case is the court's willingness to limit the press in such a public setting. ${ }^{182}$ Recognition of public zones of privacy may strengthen individuals' ability to control their own images but not without serious costs to press freedoms and to truthful news reporting. Although the court arguably aimed its ruling at "realitybased" programming, ${ }^{183}$ by expanding the tort of intrusion, this decision threatens to chill future investigative reporting, particularly on television and other modern news media. ${ }^{184}$ Understandably, we all

${ }^{182}$ See supra notes 162-65 and accompanying text (analyzing the court's finding that Shulman may pursue a claim of intrusion against the producers for recording her conversations with rescue workers). See also Shulman, 955 P.2d at 491 ("[E]xisting legal protections for communications could support the conclusion that Ruth [Shulman] possessed a reasonable expectation of privacy in her conversations with Nurse Carnahan and the other rescuers.").

${ }^{183}$ See Manny Fernandez, Tabloid TV Deall Blow in Ruling on Privacy, S.F. CHRON., June 2, 1998, at Al ("The ruling was aimed in large part at the videotaping techniques of so-called reality TV shows, nationally syndicated programs in which camera crews ride in police cars or ambulances to film people in scenes of intense personal drama, often without the subjects' knowledge.").

${ }^{184}$ See Dolan, supra note 159, at A1 (quoting media lawyer Lee Levine who warned that the Shulman decision "will have a chilling effect on the use of reporting techniques" because it gave the media little guidance on "which techniques can be used and which cannot"); Mike Katoaka, Privacy Ruling Likely to Affect Media Coverage, PRESSENIERPRuSE (Riverside, Cal.), June 2, 1998, at A3 (quoting law professor Kurt Manheim who cautioned that " $[\mathrm{p}]$ roducers are going to have to be more careful in getting these people to sign releases. If they can't get consent, they can't use the footage-which affects the public's right to know.").

The chilling effect that rulings such as this will have on news media is readily ob- 
might want to be let alone after a serious car accident, but, although the result of this decision may satisfy our vindictive urges regarding unpopular media, the protections it offers will only infinitesimally further our personal privacy. The harm to press freedoms is likely to be substantial, and in the long run, the loss to individual liberty severe. ${ }^{185}$

\section{THE SANDERSDECISION}

The California Supreme Court affirmed its holding in Shulman one year later with its decision in Sanders v. American Broadcasting Co. ${ }^{186}$ In reversing a judgment of the Court of Appeals in favor of a television news network, the court continued to expand the scope of what constitutes a reasonable expectation of privacy. The plaintiff in this case, Mark Sanders, worked as a telepsychic for the Psychic Marketing Group ("PMG") where he gave "readings" to callers of PMG's 900 number. ${ }^{187}$ Stacy Lescht, an investigative reporter for defendant $A B C$, also secured a job with PMG as a "reader." ers, Lescht engaged in conversations with her fellow workers, including Sanders. ${ }^{189}$ Lescht videotaped these conversations from a small camera hidden in her hat and recorded them with a microphone hid-

servable. Jane Kirtley, Executive Director of The Reporters Committee for Freedom of the Press, explains that large corporations have begun attacking reporters' newsgathering techniques in order to "prevent or deflect bad publicity" by shifting the focus away from their own conduct. Jane E. Kirtley, Vanity and Vexation: Shifting the Focus to Media Comduct, 4 WM. \& MARY BILL OF RTS. J. 1069, 1070 (1996). She cites, for example, a decision by CBS not to air a 60 Minutes story featuring an interview with a tobacco executive who criticized his former employer, the Brown \& Williamson Tobacco Corporation, because of fears that the network would be sued for tortious interference. See id. at 1069-70.

Steve Solomon, a law professor at New York University, notes that “[o]ne of the most active areas in litigation right now is on news-gathering tactics of the press. It's sort of a growth industry for lawyers." Brownfield, supra note 95, at F1. Similarly, Judge Forer observed that over one 46-day period, eight defamation suits were filed against the Philadelphia Inquirer, a reputable source of news. See FORER, supra note 100, at 164 ("The Inquirer is not the National Enquirer. It does not engage in sensationalism or irresponsible charges."). Given the high cost of defending these suits, she concludes that economic pressures will force compromises in news reporting. See id. ("Punishing verdicts against the press and other news media inevitably have an effect on policy as to what will be published or aired.").

${ }_{185}$ A final postscript to Ruth Shulman's story: after remand, the parties settled their dispute in September 1999 for an undisclosed sum. See Gail Diane Cox, Privacy vs. Reality TV Suit Settled, NAT'L L.J., Sept. 20, 1999, at A6.

${ }^{186} 978$ P.2d 67 (Cal. 1999).

${ }^{187}$ See id. at 69 .

${ }^{183}$ See id. at 70 .

${ }^{189}$ See id. 
den in her blouse. ${ }^{190}$ A short excerpt from these conversations was subsequently included in a broadcast segment on ABC's PrimeTime Live about the telepsychic industry. ${ }^{191}$ Sanders charged that, by secretly recording workplace conversations, Lescht and $\mathrm{ABC}$ intruded on his privacy. ${ }^{192}$

\section{A. Another Case of Intrusion}

The key question addressed by the court in Sanders was whether Sanders had a reasonable expectation of privacy from covert videotaping by a television reporter in a workplace setting where his conversations could be seen and heard by fellow workers but not by the general public. ${ }^{193}$ Expanding on its decision in Shulman, the court concluded that he did, noting that "privacy, for purposes of the intrusion tort, is not a binary, all-or-nothing characteristic .... [T] he fact the privacy one expects in a given setting is not complete or absolute does not render the expectation unreasonable as a matter of law." The court then used this definition of privacy to define seclusion as well, adding that '[1]ike 'privacy,' the concept of 'seclusion' is relative. The mere fact that a person can be seen by someone does not automatically mean that he or she can legally be forced to be subject to being seen by everyone. ${ }^{195}$

The extension of Shulman's levels of privacy reasoning in this case is alarming. ${ }^{196}$ The court accepts Sanders's contention that while he may not be able to claim an expectation of privacy in the content of his conversation with Lescht, he may claim such an expectation in the conduct of that conversation. ${ }^{197}$ There is no reasonable justification for this distinction, yet by making it, the court leaves the press painfully

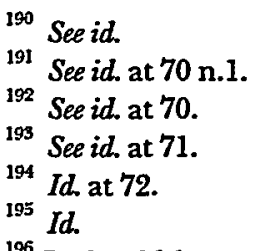

${ }^{196}$ It should be noted that while the court's decision in Shulman was issued by a plurality opinion, splitting five to two on the question of intrusion, the court in Sanders was unanimous on the issue. Compare Shulman W Prods., 955 P.2d 469 (Cal. 1998), with Sanders, 978 P.2d 67.

197 See Lee Levine \& Jay Ward Brown, Shulman v. Group W and Sanders v. ABC: Califormia Crafts the Contours of Its Privacy Torts, FIRST AMENDMENr \& MEDIA LITIG. (ABA/First Amendment and Media Litig. Comm.), Winter 1999, at 1, 15 (discussing the plaintiffs' argument in Sanders). 
exposed while reporters and angry plaintiffs sort out new boundaries. ${ }^{198}$

\section{B. Problems with Bugs}

Cut off by the First Amendment from punishing the press for reporting a story, the court in both Sanders and Shulman attacked means of newsgathering instead. This is not altogether surprising, for public anger at media is often coupled with widespread fear of newsgathering technologies. People respond negatively, and often irrationally, to the press's use of small recording devices, telephoto lenses, and parabolic microphones. In these cases, permitting attacks on newsgathering without considering the First Amendment results in liability for accurate and arguably important news stories.

In Sanders, the plaintiff's comments were not private. He conceded that workers sitting in adjacent cubicles likely could have overheard his conversations with Lescht. ${ }^{199}$ The court, however, held that "a person may reasonably expect privacy against the electronic recording of a communication, even though he or she had no reasonable expectation as to confidentiality of the communication's contents. ${ }^{200}$ This is not the same as wiretapping a telephone conversation, where a speaker secluded in a phone booth might reasonably expect that a conversation cannot be overheard and recorded and for which criminal sanctions exist. ${ }^{201}$ Others in the room who overheard the conversations could have passed Sanders's comments on to the press (or perhaps more harmfully, to his boss) without fear of liability. Offended at the use of electronic recording devices, and perhaps more importantly by Lescht's covert tactics, the court imposed liability.

The same prejudice was apparent in the Shulman decision.

198 The recent court battle over an $\mathrm{ABC}$ Primetime Live segment that exposed mishandling of meat products at a grocery store chain illustrates the point. Although the Fourth Circuit eventually sharply limited ABC's liability, this came only after years of litigation in which the chain never contested the accuracy of the report but initially won a jury award that included $\$ 5$ million dollars in punitive damages. See Food Lion, Inc. v. Capital Cities/ABC, Inc., No. 97-2492, 1999 U.S. App. LEXIS 5863, at *49 (4th Cir. Oct. 20, 1999).
199 See Sanders, 978 P.2d at 70.
${ }^{200} I d$. at 72 (emphasis added).
201 See CAL. PENAI CODE $\$ 631$ (West 1998) (criminalizing wiretapping); CAL. PENAI CODE § 632(a) (West 1998) (prohibiting use of "any electronic amplifying de- vice" to "eavesdrop upon or record the confidential communication" of others "with- out the consent of all parties to a confidential communication" and further providing that offenders may be punished with a maximum jail term of one year). 


\section{Public Privacy}

As in Shulman, the Sanders court allowed a plaintiff who clearly failed to meet the burden for a private facts claim nonetheless to seek liability for a news report under the intrusion tort. The facts in Sanders are distinguishable to the extent that the reporter in this case used more covert tactics than those employed in the Shulman case, where the producers made no effort to hide either the camera or the microphone. Nonetheless, as with Shulman, had the reporter in this case simply described what she saw and heard in a more traditional news "report," her actions would not have given rise to liability. Sanders's comments were not privileged; only because a reporter recorded them did they become subject to liability. This result is hard to swallow if First Amendment freedoms are to retain their teeth.

\section{Legislattve EXCESSES IN "PaPARAZZi LawS"}

The death of Princess Diana stirred more public outrage against the press. ${ }^{202}$ That anger was fueled by the rhetoric that followed the accident, climaxing with Earl Spencer's "blood on their hands" eulogy for his sister. ${ }^{203}$ In the United States, the shock associated with the tragedy combined with "longstanding complaints" by celebrities against the swarms of "paparazzi" photographers, strengthening the belief that "there ought to be a law" to prohibit perceived media excesses. $^{204}$ The surge in momentum for new media restrictions to protect personal privacy, however, ignored the facts of the accident, ${ }^{205}$ and the "substantial body of existing state law [that] already protects against dangerous or unreasonably invasive conduct, regardless of whether a camera is involved. ${ }^{206}$

${ }^{202}$ See Larysa Pyk, Putting the Brakes on Paparazzi: State and Federal Legislators Propase Privacy Protection Bills, 9 J. ART \& ENT. L. 187, 188 (1998) (describing the public's response to Diana's tragic death).

${ }^{203}$ See Howard Kurtz, Pictures at a High Price, WASH. POST, Sept. 1, 1997, at A1 (describing Earl Spencer's invectives against the press).

${ }^{204}$ See Legislation Aimed at "Paparazzi" Places All Joumalists at Risk, LIBEI DEF. RESOURCE CENTER BULI. (Libel Defense Resource Ctr., New York, N.Y.), Dec. 23, 1998, at i [hereinafter Legislation Aimed at "Paparazzi"] (noting the effect of Princess Diana's death and Earl Spencer's "blood on their hands" eulogy in the United States).

${ }^{205}$ It should be noted that after completing their investigation of the accident, French judges absolved the photographers of any responsibility, determining that the accident was caused by the driver of Princess Diana's vehicle, Henri Paul, who was intoxicated. See Marlise Simons, French Magistrates Clear Photographers in Death of Diana, N.Y. TIMES, Sept. 4, 1999, at A2.

${ }^{206}$ Legislation Aimed at "Paparazzi," supra note 204, at i (noting that the demand to 
Although the public generally favors efforts to expand privacy ${ }^{207}$ responding ironically to images and stories it sees in media-it has not come forth with a groundswell of grass-roots support for legislative action. $^{208}$ Rather, the proponents of privacy are those individuals who stand to profit most from its protection ${ }^{209}$ - a group that most likely does not include the average citizen. ${ }^{210}$

In a media-driven society, the power to control one's own image is a valuable asset. While tied to privacy-most people would prefer to avoid a camera before their first cup of coffee and a morning shower ${ }^{211}$ - this does not suggest a desire to escape totally from the public eye. On the contrary, celebrities want to control when and how media portray their image. They are motivated chiefly by profit with an eye toward what story-and what degree of attention-will maximize box office potential.

There is nothing constitutionally suspect about profit or about maximizing box office appeal to get more of it, unless the marquee is built on the ruin of press freedom. To that effect, California's new "paparazzi law" is dynamite under the foundations of the First Amendment.

curb the media disregarded the "actual facts" of the accident and already existing law).

${ }^{207}$ See Franzen, supra note 32, at 51 (observing that because of a pervasive sense that " $[t]$ here is less privacy than there used to be[,]" most Americans "now dutifully tell pollsters that they're very much worried about privacy").

${ }^{203}$ See id. at 48 (noting that paranoia about privacy is "missing one vital ingredient: a genuinely alarmed public").

${ }^{209}$ The foremost promoter of privacy is likely the powerful entertainment lobby. Celebrities seek to control use of their image in order to maximize their personal profitability. This was demonstrated by the witnesses appearing before a May 1998 hearing of the House Judiciary Committee. Speaking in favor of legislation that would expand protections from intrusion were actors Michael J. Fox and Paul Reiser, actor and President of the Screen Actors Guild, Richard Masur, and entertainment publicist Dick Guttman. See Protection from Personal Intrusion Act EO Privacy Protection Act of 1998: Hearing on H.R. 2448 E H.R. 3224 Before the House Comm. on the Judiciary, 105th Cong. (1998), available in Testimony Presented to Full Commiltee on the Judiciary (last modified May 4, 1999) <http://www.house.gov/judiciary/10141.htm>. Additional letters of support where sent to the committee by actors Tom Cruise, Barbra Streisand, Tom Hanks, Billy Crystal, Sharon Stone, Whoopi Goldberg, Michelle Pfeiffer, Richard Dreyfuss, Antonio Banderas, Melanie Griffith, Brooke Shields, Helen Hunt, Goldie Hawn, Kevin Spacey, Laura Dern, and Billy Bob Thornton. See SAG Leads Delegation at Personal Privacy Hearing in U.S. House Judiciary Committee, 39 NAT'L SCREEN ACTOR MAG. (July 1998) <http://www.sag.org/publications/July98screenactor.html\#privacy>.

${ }^{210}$ See Franzen, supra note 32, at 50 (commenting on the author's own limited risk of being a victim of the First Amendment: "with two hundred and seventy million people in the country, my own chances of being nationally exposed are next to nil").

${ }_{211}$ See Hyman Gross, Privacy and Autonomy, in PRIVACY 169, 176 (J. Roland Pennock \& John W. Chapman eds., 1971) (describing privacy as the right to exercise "editorial privilege" over how others in society view us). 


\section{A. S.B. 262: Hollywood Strikes Back}

Led by the Screen Actors Guild, the powerful celebrity lobby in California seized on the public response to Princess Diana's death and within thirteen months, Governor Pete Wilson signed new legislation purporting to extend privacy protections. ${ }^{212}$ "Under this bill," Governor Wilson declared, "the so-called 'stalkerazzi' will be detered [sic] from driving their human prey to distraction-or even death.,213 Eager to capitalize on public fears and sympathies, the Governor's office added: "This legislation protects not only celebrities, but also those who have never sought publicity, but became media targets because they were victims of crime. ${ }^{, 214}$ Despite these lofty concerns for personal liberty, the new law poses grave threats to First Amendment freedoms.

The bill creates new causes of action for physical invasion of privacy and constructive invasion of privacy. ${ }^{215}$ The physical invasion of privacy tort, defined in subsection (a), expands common law protections from intrusion by shifting the analysis of the wrongful act from the reasonable expectations of the plaintiff to the state of mind of the alleged intruder. ${ }^{216}$ Under the amended code, a physical invasion of privacy occurs when a defendant

knowingly enters onto the land of another without permission or otherwise committed a trespass, in order to physically invade the privacy of the plaintiff with the intent to capture any type of visual image, sound recording, or other physical impression of the plaintiff engaging in a personal or familial activity and the physical invasion occurs in a manner that is offensive to a reasonable person. ${ }^{217}$

Despite suggestions to the contrary by the bill's promoters, ${ }^{218}$ the statu-

${ }^{212}$ See SAG Hails Passage of Califormia Privagy Law, 40 NAT'L SCREEN ACTOR MAG. (Nov. 1998) (visited Jan. 9, 2000) <http://www.sag.org/publications/Nov98 screenactor.html\#privacys (reporting that the Screen Actors Guild "developed a broad coalition to support S.B. $262^{\prime \prime}$ ).

${ }^{213}$ Governor's Office, supra note 42 (announcing Governor Wilson's signing of the privacy legislation).

${ }^{214}$ Id. Citing a report by the National Victim Center, the press release continues: "[O]ne rape victim was unknowingly taped by a tabloid television show using a highpowered lens as she prepared her family's dinner in her own kitchen. The media went so far as to report the titles of the books on the shelves in her two-year-old daughter's nursery." Id.

${ }^{215}$ See id. ("S.B. 262 ... creates a statutory cause of action for invasion of privacy which will apply to trespass or 'constructive' trespass ....").

${ }^{216}$ See CAL. CJv. CODE $§ 1708.8$ (a) (West Supp. 1999).

217 Id.

${ }^{218}$ See Governor's Office, supra note 42 (asserting that the bill applied to "personal 
tory language requires no reasonable expectation of privacy for the plaintiff to pursue a cause of action. Thus, unlike previous applications of intrusion, photographs of plaintiffs "engaging in 'personal or familial' activities in the front yard of their home, in plain view of the public" could give rise to liability if the photographer entered the space "in order to physically invade the [plaintiff's] privacy.",219

The bill expands the common law's traditional definition of "privacy" beyond intimate personal details like sexual relations and medical conditions to include ordinary "interactions with the plaintiff's family" or "other aspects of plaintiff's private affairs or concerns. ${ }^{, 220}$ It does so, however, without further defining the scope of protection, raising serious questions about where First Amendment protection ends and privacy protection begins. The willingness of lawmakers to cast out such broad veils of secrecy without regard to press freedoms is alarming, despite the rationale of personal privacy. ${ }^{22}$

Subsection (b) of the new law affords protection from what it deems "constructive invasion of privacy. ${ }^{, 222}$ It prohibits photographers and reporters from capturing "images or recordings using sensory enhancing devices" if doing so would otherwise have required trespass. ${ }^{223}$ Constructive invasion of privacy occurs

or family activity in circumstances where [the plaintiff] had a reasonable expectation of privacy").

${ }^{219}$ Hogue \& Stanley, supra note 44 , at $30-31$. It is further noted that

[t]he Legislative history includes a recognition that the courts do not recognize an expectation of privacy in public places. ... However, as the committee analysis impliedly acknowledges, the reasonable expectation of privacy element only appears in the statute's definition of constructive invasion of privacy, subdivision (b). The reasonable expectation of privacy element does not appear in subdivision (a) which governs liability for physical invasion of privacy.

Id. at 31 n.4 (construing Assembly Committee on Judiciary, Analysis of S.B. 262 at 4 (July 28, 1998)).

${ }^{220}$ CAL. CIV. CODE $\$ 1708.8(k)$ (West Supp. 1999). Subsection (k) provides in full: For the purposes of this section "personal and familial activity" includes, but is not limited to, intimate details of the plaintiff's personal life, interactions with the plaintiff's family or significant others, or other aspects of plaintiff's private affairs or concerns. Personal and familial activity does not include illegal or otherwise criminal activity as delineated in subdivision (f). However, "personal and familial activity" shall include the activities of victims of crime in circumstances where either subdivision (a) or (b), or both, would apply.

Id.

${ }^{221}$ See Boese, supra note 31 , at 1, 23 (noting that "the poorly drafted language in California's anti-paparazzi law opens" a Pandora's box of issues that will take years to sort out).

${ }^{222}$ CAL. CIV. CoDE § 1708.8(b) (West Supp. 1999).

${ }^{223}$ Id. 
when the defendant attempts to capture, in a manner that is offensive to a reasonable person, any type of visual image, sound recording, or other physical impression of the plaintiff engaging in a personal or familial activity under circumstances in which the plaintiff had a reasonable expectation of privacy, through the use of a visual or auditory enhancing device, regardless of whether there is a physical trespass, if this image, sound recording, or other physical impression could not have been achieved without a trespass unless the visual or auditory enhancing device was used.

While this section retains the common law requirement of a "reasonable expectation of privacy," like subsection (a), it lowers the standard of proof, requiring only that the intrusion be "offensive to a reasonable person. ${ }^{225}$

The more significant flaw in this section, however, is the absence of any definition of a "visual or auditory enhancing device. ${ }^{226}$ While one reasonably can assume the intention to restrict uses of parabolic microphones and telephoto lenses, what treatment should courts give to eyeglasses or hearing aids? Certainly, they qualify as "enhancing devices." Given the language of the statute, it seems that a couple, reasonably believing that a conversation on their front porch is out of earshot to an elderly reporter standing on the sidewalk, would have a cause of action if that reporter happened to be wearing an ordinary hearing aid that allowed him to record the conversation in his note pad. Meanwhile, the same couple would not have a cause of action against a reporter with extraordinarily sharp hearing when he overhears a conversation through their open bedroom window. There is no rational justification for this distinction. In both cases, the couple could have secured adequate protection under existing laws. ${ }^{227}$ In the

${ }^{224} I d$.

225 See Hogue \& Stanley, supra note 44, at 31 (noting that in this new construction, the common law's "highly offensive" requirement is dropped).

${ }^{226}$ Even proponents of the legislation have expressed concern about its vague terms, particularly about the potential impact on law enforcement activities. See Pyk, supra note 202, at 200 (noting potential problems with "vagueness of terms"); see also Andrew D. Morton, Comment, Much Ado About Newsgathering: Personal Privacy, Law Enforcement, and the Law of Unintended Consequences for Anti-Paparazzi Legislation, 147 U. PA. L. REV. 1435, 1464-71 (1999) (examining the potential implications of anti-paparazzi legislation on the scope of law enforcement surveillance).

227 Existing law already provides privacy protections that recognize this distinction without the confusion created by references to "enhancing devices" in this statute. Compare People v. Mendoza, 176 Cal. Rptr. 293, 294 (App. Dep't Super. Ct. 1981) (holding that there is no reasonable expectation of privacy in a yard enclosed by a chain link fence), with People v. Lovelace, 162 Cal. Rptr. 65, 69 (Ct. App. 1981) (finding a reasonable expectation of privacy in a backyard surrounded by a six-foot fence, even though activities in the yard can be seen through knotholes and gaps in the 
first example, however, if they do not like what they read in the next morning's newspaper, they also have a cause of action for intrusion. ${ }^{22}$

Much like the California Supreme Court's holdings in Shulman and Sanders, California's anti-paparazzi statute shifts the focus of privacy law away from traditional causes of action to a new, expanded view of intrusion. It thus circumvents decades of carefully crafted judicial balancing between press freedoms and appropriate protections for privacy in a manner that recklessly jeopardizes First Amendment liberties.

\section{B. Casting a Bigger Net: Intrusion Goes to Washington}

Federal lawmakers have not missed the opportunity to capitalize on anti-media sentiments, proposing four separate bills aimed at prohibiting paparazzi behavior. ${ }^{229}$ The bills are similar in content to the California law and focus on the harassment of individuals by members of the press. ${ }^{230}$ The federal bills express more open hostility toward the media ${ }^{231}$ and in some cases more clearly reflect the public outrage

fence), and People v. Arroyo, 174 Cal. Rptr. 678, 682 (App. Dep't Super. Ct. 1981) (finding a reasonable expectation of privacy in an enclosed backyard patio).

${ }^{228}$ Commentators have identified other vagaries in the statute that raise more troubling questions for its application. See, e.g., Boese, supra note 31, at 1, 23 (noting the lack of guidance on what constitutes "personal or familial activity" or what is meant by "offensive to a reasonable person").

${ }^{229}$ Four federal anti-paparazzi bills were introduced in the 105th Congress: H.R. 2448 (the "Protection from Personal Intrusion Act") by late Congressman Sonny Bono of California, H.R. 3224 (the "Privacy Protection Act of 1998") by Congressman Elton Gallegly of California, H.R. 4425 (the "Personal Privacy Protection Act") by Congressman John Conyers of Michigan, and S. 2103 (the "Personal Privacy Protection Act") by Senator Diane Feinstein of California and Senator Orrin Hatch of Utah. See H.R. 4425, 105th Cong. (1998); S. 2103, 105th Cong. (1998); H.R. 3224, 105th Cong. (1998); H.R. 2448, 105th Cong. (1997). For brief descriptions of the proposed bills, see Pyk, supra note 202, at 193-97 and Legislation Aimed at "Paparazzi", supra note 204, at 1-6.

${ }^{230}$ But see Legislation Aimed at "Paparazzi", supra note 204, at 1 (noting that unlike the California law, the proposed federal bills limit liability to direct participants and not to those who induce others to violate the law).

${ }^{231}$ For example, the "Personal Privacy Protection Act" by Senators Feinstein and Hatch makes the following findings:

(1) Individuals and their families have been harassed and endangered by being persistently followed or chased in a manner that puts them .... in danger of serious bodily injury or even death, by photographers, videographers, and audio recorders attempting to capture images or other reproductions of their private lives for commercial purposes....

(3) Such harassment and trespass threatens not only professional public persons and their families, but also private persons and their families for whom personal tragedies or circumstances beyond their control create media interest. 
over Princess Diana's death than the California statute. ${ }^{232}$

The sudden proliferation of these bills in response to a highly publicized tragedy, however, suggests precisely what is wrong with them: they are knee-jerk reactions to public anger toward the paparazzo press. Consequently, they are poorly thought out and threaten to cast too wide a net of privacy protection at the expense of legitimate news reporting and important First Amendment freedoms.

Perhaps recognizing the danger, Hollywood publicist Dick Guttman, testifying in support of federal legislation before the House Judiciary Committee, contrasted paparazzi with "stalkerazzi." "stalkerazzi," he explained, are "tabloid predators who conduct guerrilla warfare through acts of pursuit and provocation rather than acts of news gathering, ${ }^{234}$ and thus are the proper targets of restrictive legislation. Paparazzi, on the other hand, are "a legitimate part of the Hollywood publicity mill., ${ }^{235}$ Public debate, however, fails to make this distinction, and, certainly, the proposed bills do not reflect it.

The entertainment industry has no reason to be seriously concerned about drawing distinctions between dangerous "stalkerazzi" and legitimate "paparazzi. ${ }^{236}$ Celebrities selling their personal image would like to tighten their control over both (and, by extension, over the mainstream press as well). The blurring of the line between news

\section{S. 2103,105 th Cong. $§ 2$ (a) (1998).}

${ }^{232}$ See H.R. 2448 \$ 1822(a)(1) (establishing criminal punishment of "not less than 20 years imprisonment and a fine" when harassing behavior by media results in death).

${ }_{233}$ See Hearing on H.R. 2448 Before the Honse Comm. on the Judiciary (1998) (statement of Dick Guttman, publicist) (visited Dec. 22, 1999) <http://www.house.gov/ judiciary.10150.htm>.

${ }^{234} I d$.

235 Id.

${ }^{236}$ Indeed, the concerns raised by celebrities promoting new legislation already are addressed by existing laws. Testifying before the House Judiciary Committee, Michael J. Fox complained that tabloid photographers had surreptitiously entered a hospital to take pictures of his newborn children. See Hearing on H.R. 2448 Before the Comm. on Judiciary (statement of Michael J. Fox, actor) (visited Dec. 22, 1999) <http:// www.house.gov/judiciary/10142.htm >. Privacy rights in hospitals, however, already are well established. See supra note 160 (referring to a Missouri case recognizing the right to privacy in receiving medical treatment). Similarly, actor Paul Reiser, referring to an incident involving fellow actor Arnold Schwarzeneggar, argued that "[r]amming an actor's car as he picks up his children from school in the hopes of getting a sensational video is not-I believe-acceptable news gathering." See Hearing on H.R. 2448 Before the Comm. on Judiciary (statement of Paul Reiser, actor) (visited Dec. 22, 1999) <http:// www.house.gov/judiciary/10143.htm $>$. Reiser is correct, of course. Those "journalists" were sentenced to fines and jail terms under existing laws prohibiting false imprisonment. See Boese, supra note 31, at 1 . Reiser fails to mention this, however, in his request for new legislation for even tighter restrictions on press freedoms. 
and entertainment aids their ability to do so. ${ }^{237}$ The more power public figures have to chill the freedoms of the press, the greater control they have in crafting their own stories for public consumption. If the press is to keep its watchdog role, this result is unacceptable.

\section{CONCLUSION: SNUFFING THE "STALKERAZZI" . . AND SPEECH}

"Celebrity is the pox of success." - Harrison Ford ${ }^{238}$

Privacy is as elusive conceptually as it often seems to be in life. It is intangible, even more so than speech which is at least recordable in print or on tape, and its amorphous nature makes it difficult to define in a legal context, despite centuries of our best efforts. Nonetheless, in a culture that values personal space, privacy is a cherished, if not wholly identifiable, "right." Its very abstraction, however, can pose serious threats to a free society.

On the one hand, protecting personal privacy from the sinister eyes of government is a fundamental pillar of our constitutional system. ${ }^{239}$ The Fourth Amendment's protections from unlawful search and seizure are essential to the preservation of democracy; thus, privacy cannot become so abstract that it disappears altogether. On the other hand, privacy often becomes an intellectual club to curb perceived media excesses by striking out at an unpopular press. Angry plaintiffs can wield it to fight back against feared encroachments by new, potentially invasive technologies. In this sense, privacy is not a defensive wall protecting personal space, but an offensive weapon that threatens free and unfettered speech.

The First Amendment is not an impenetrable shield, and I would not argue that every spoken word or printed page deserves equal constitutional protection. Libelous speech is harmful, but laws exist to protect against this offense. Nor would I suggest that an individual's

237 "News" shows like Entertainment Tonight and Access Hollywood, for example, are simply bullhorns for the entertainment industry. See generally Catherine Seipp, The Puppet Masters, AM. JOURNAIISM REV., Oct 1999, at 22, 24-25 (describing the increasing power of celebrity publicists to control their clients' presentation in magazines and on television).

${ }^{238}$ Michael Birt, Talking Pictures, TALK, Sept. 1999, at 96, 97.

239 The press, it should be noted, has long played a pivotal role in preserving this protection. See PEMBER, supra note 114, at 231 (noting that "the press is not the villain; in fact, the press is often an ally in the fight against snooping, bugging, personality testing, and the many other devious attacks upon individual privacy"). 
existence in and of itself opens his or her life to the prying eyes of media. As we commute to work in the solitude of our personal automobiles or surf the net from the serenity of our bedrooms, however, it is apparent that zones of privacy already enjoy a multitude of protections. We must be careful, therefore, in our zeal to snuff the "stalkerazzi," (who, from the quiet vantage point of our living room sofas, are certainly a despicable bunch) that we do not also silence the next Woodward or Bernstein.

The more compassionate among us might have thought more carefully about Ruth Shulman before videotaping her in the aftermath of a tragic accident involving her family that will leave her in a wheelchair for the rest of her life. Effective journalism, however, is not for the weak of heart. It often demands sharp questions and probing investigations. With this in mind, while we can and should expect decency and respect from the reporters who cover news, we set dangerous precedent when we decide that a story cannot be told at all. 
